\title{
Reducing Fall Among Acute Rehabilitation Patients Through Implementation of a Video Monitoring System
}

\author{
Priscila Alfonso \\ University of St. Augustine for Health Sciences, p.alfonso@usa.edu
}

DOI: https://doi.org/10.46409/sr.AQZY9871

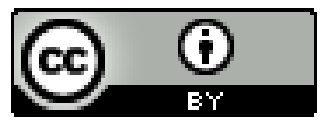

This work is licensed under a Creative Commons Attribution 4.0 License.

Follow this and additional works at: https://soar.usa.edu/scholprojects

Part of the Health Information Technology Commons, and the Rehabilitation and Therapy Commons

\section{Recommended Citation}

Alfonso, P. (2021). Reducing Fall Among Acute Rehabilitation Patients Through Implementation of a Video Monitoring System. [Doctoral project, University of St Augustine for Health Sciences]. SOAR @ USA:

Student Scholarly Projects Collection. https://doi.org/10.46409/sr.AQZY9871

This Scholarly Project is brought to you for free and open access by the Student Research at SOAR @ USA. It has been accepted for inclusion in Student Scholarly Projects by an authorized administrator of SOAR @ USA. For more information, please contact soar@usa.edu, erobinson@usa.edu. 
Reducing Falls Among Acute Rehabilitation Patients Through Implementation of a Video Monitoring System: An Evidence-

\section{Based Project}

Priscila Alfonso, MSN/ED

School of Nursing, University of St. Augustine for Health Sciences

This Manuscript Partially Fulfills the Requirements for the

Doctor of Nursing Practice Program and is Approved by:

Course Faculty: Sue Bingham, PhD

Preceptor: Michelle Sterling, DNP

Date of Final Approval written as: April 5, 2021 


\begin{abstract}
Practice Problem: Falls are a significant healthcare issue that leads to substantial patient suffering and exorbitant health care expense. The Centers for Medicare and Medicaid Services (CMS) identify falls as preventable and not eligible for reimbursement.

PICOT: The PICOT question that guided this project was: for acute rehabilitation inpatients (P), will the continuous use of video monitoring (VM) (I) compared to using bed alarms (C), decrease the fall rate by $10 \%(\mathrm{O})$ within six weeks of implementation $(\mathrm{T})$ ?

Evidence: The practice recommendation for using a VM system as a primary intervention or part of a multifactorial comprehensive fall prevention strategy was recommended in the literature to improve patient safety and outcomes.
\end{abstract}

Intervention: VM surveillance was used to decrease the prevalence of falls in moderate to high fall risk traumatic brain injury (TBI) patients on a rehabilitation unit. VM technicians verbally refocused patients and quickly alerted staff to potential falls.

Outcome: The intervention achieved a $49 \%$ reduction in the hospital fall rate per 1,000 patient days, $65 \%$ in the rehabilitation fall rate per 1,000 patient days, $100 \%$ reduction in the TBI fall rate per 1,000 patient days, and a $30 \%$ reduction in cost for $1: 1$ sitter.

Conclusion: This clinical project demonstrated support for the use of live VM surveillance to decrease fall rates on a TBI unit. As a result, this evidence-based project (EBP) project was recognized as improving the organization's clinical care. 
REDUCING FALLS AMONG ACUTE REHABILITATION PATIENTS....3

Reducing Falls Among Acute Rehabilitation Patients Through the Implementation of Video Monitoring System: An Evidence-based Project

Hospital-acquired falls are a serious health problem that can diminish the quality of life and cause deaths (Soncrant, Neily, Bulat, \& Mills, 2019). Falls in hospitals lead to anxiety, discomfort, reduced healing, lengthier inpatient stays, and additional health-related problems. Falls may also cause patient distress and affect the quality of life. Falls have a high prevalence in the hospital setting, causing a severe patient safety risk, particularly to the elderly population (Ronald et al., 2012). Regardless of the efforts in healthcare organizations to identify patients in danger for falls and employ fall preventive measures, the prevalence of falls among hospitalized patients in the United States remains a significant health care concern; with falls occurring in approximately 700,000-1,000,000 hospitalized patients per year (Cox et al., 2015). Approximately twenty percent of hospitalized patients experience a fall event, which may result in physical harm, suboptimal quality of life, emotional and mental pain, and suffering (Hodo, Munsterman, \& Newomb, 2018). Falls and related injuries are a global public health problem anticipated to worsen with the increasing aging population (Vanderberg et al., 2017).

This evidence-based practice (EBP) project was aimed to determine the impact of implementing a video monitoring (VM) system in the traumatic brain injury (TBI) unit as an intervention to reduce the prevalence of falls within six weeks. This paper will describe an EBP project that will include the significance of the practice problem, the PICOT question, EBP model and change framework, literature search strategy and themes, the setting, implementation considerations and a plan, an evaluation plan, results, dissemination, conclusions, and practice recommendations. 


\section{Significance of the Practice Problem}

Prevention and reduction of falls is an important goal of hospitals throughout the world. According to the World Health Organization ([WHO], 2018), an estimated 646,000 individuals die from falls globally each year. Over $80 \%$ are in low-and middle-income countries, and 37.3 million are severe enough to require medical attention each year (WHO, 2018). In 2017, the Centers for Disease Control (CDC) reported injuries related to falls lead to prolonged hospitalization, surgery, and death. The Centers for Medicare and Medicaid Services (CMS) noted that injurious falls were an identified hospital-acquired condition (HAC), which was considered preventable when EBP guidelines are used (CMS, 2011). In 2008, CMS discontinued reimbursement for any HAC treatments, such as injuries due to falls in acute care. Studies have shown increased hospital costs and increased inpatient stay lengths by 6.3 to 12 days because of serious falls (Dykes, et al., 2018). Fatal falls resulted in an approximate treatment cost of \$34 billion, with a projected increase to approximately $\$ 67.7$ billion by 2020 (Dykes et al., 2018). California reported about 74,945 fall cases and 1,733 deaths in 2013 (CDPH.ca.gov). In 2007, almost 30,000 people were injured in falls in Los Angeles County, and approximately 400 died because of their fall; those numbers are expected to rise with an aging population. (publichealth.lacounty.gov, 2008). Since the Institute of Medicine's hospital safety report was published, patient safety became the primary focus for regulatory accreditation agencies, as well as numerous government and private agencies, such as the Agency for Healthcare Research and Quality, the Joint Commission (TJC), healthcare organizations, and providers, including the nursing discipline (Donaldson, 2018). These regulatory and accreditation agencies have established best practices and preventive safety measures (Donaldson, 2008). 


\section{REDUCING FALLS AMONG ACUTE REHABILITATION PATIENTS....5}

Within the hospital organization for this EBP project, the 2019 data showed approximately 123 fall events or a mean fall rate of 4.57 per 1,000 inpatient days. There were 15 falls in the TBI unit for 2019 (Rancho, 2019). This rate was higher compared to benchmarks set by the National Database of Nursing Quality Indicators (NDNQI) of 2.22 per 1,000 inpatient days (NDNQI, 2019). The high prevalence, long-standing effects, and costs of falls will affect the healthcare system progressively as time goes on (Ronald et al., 2012). The proposed EBP project was implemented at a local 150-bed inpatient rehabilitation center, part of the Los Angeles County Department of Health System (LACDHS). There are 75 acute inpatient rehabilitation beds, including 25 TBI beds (Rancho, 2019). Fall events in the TBI rehabilitation unit pose a complex patient safety issue because they may result in higher injury severity, prolonged post-traumatic amnesia, and decreased Functional Independence Measure scores (Hodo, Munsterman, \& Newcomb 2018). Reasons for falls may be attributed to a patient's diagnosis, such as TBI, lack of compliance with regulatory requirements on staffing ratio or care companions, or the use of bed alarms (Hodo, Munsterman, \& Newcomb 2018). Though falls in hospitals may not always be averted, using the most appropriate actions to reduce falls was essential. This EBP project implemented an intervention using VM for fall prevention among hospitalized TBI patients. Ethical considerations to protect the patients' rights and mitigate new types of risks, such as disruption of care, workload increase related to data management, and technology maintenance introduced to implement monitoring technologies were reviewed (Grigorovich \& Kontos, 2020).

\section{PICOT Question}

The PICOT question that guided the development of the EBP project was: For acute rehabilitation inpatients (P), will the continuous use of VM (I) compared to using bed alarms (C), 


\section{REDUCING FALLS AMONG ACUTE REHABILITATION PATIENTS....6}

decrease the fall rate by $10 \%(\mathrm{O})$ within six weeks of implementation $(\mathrm{T})$ ? The population selected for the implementation of the VM intervention were adult inpatients diagnosed with TBI; many of these patients with a history of falls have a significantly longer rehabilitation length of stay; falls are a significant cause of morbidity and mortality for children and older adults (Maas \& Manley, 2013). The intervention used 12 “Telesitters" video monitors in the adult TBI unit as part of a fall prevention program. Studies showed that patients in rehabilitation hospitals such as those with TBI, stroke, spinal cord injury, and other neurological problems are at higher risk for falls and can benefit from EBP to reduce the incidence of falls (Forrest et al., 2012). The impact of using VM on preventing falls was assessed among patients with TBI in the rehabilitation unit and compared to the incidence of falls with other rehabilitation patients on bed alarms. Designated VM technicians performed continuous live monitoring of TBI patients in a surveillance area located in the Nursing Resource Center.

\section{Evidence-Based Practice Model \& Change Theory}

The EBP model identified for this change project was the Iowa Model of EBP to promote quality care. The Iowa Model helped nurses and other healthcare providers adopt the best evidence into clinical practice while improving patients' outcomes. The Iowa Model steps include: 1) identify a problem-focused trigger, such as the identification of a clinical problem like patient falls, 2) determine if the clinical problem is a priority for the organization, 3 ) form a team, 4) compile and evaluate relevant studies related to the practice change by the team, 5) critiques of presented studies by the team to ascertain whether the project with the established intervention is scientifically appropriate, 6) implement the intervention into a pilot practice change, and 7) evaluate the practice change (Brown, 2014). 


\section{REDUCING FALLS AMONG ACUTE REHABILITATION PATIENTS....7}

The change model identified as most consistent with the author's organizational structure and professional experience was Kurt Lewin's Model of Change. "Changes to organizational patterns (new workflow, policies \& procedures) will surely occur within the organization as it adapts to sustained practices. Relationships between practices and their systems exist using Kurt Lewin's 3-step change model of Unfreezing, Movement, and Refreezing” (Manchester et al., 2014, p.82).

The processes and outcomes of the project were influenced by multiple stakeholders' (fall prevention team) perspectives at the planning, implementation, and evaluation phases of the change process. Lewin's first phase is changing the traditional approach (Unfreezing), highlighting the emergent team behaviors (Movement), and strengthening the behaviors through changes in organizational structure (Refreezing). Kurt Lewin's change model has previously been applied to understanding how health professionals' behaviors become accepted and sustained in clinical settings (Manchester et al., 2014). This change model guided the EBP project.

\section{Evidence Search Strategy}

The evidence search strategy process started with conducting a focused search using the clinical problem to direct the search. The other search strategy steps used included the identification of keywords, the selection of relevant library databases to identify primary sources, the review of titles for relevance to the clinical problem, which ensured that the articles met inclusion criteria, the review of abstracts, retrieval of full-text articles, critical appraisal, and the development of summary and the syntheses of strengths and recommendations for each of the articles (Adorno, Garbee, \& Marix, 2016). An essential step in the search process was gathering recent evidence that was scholarly and peer-reviewed to accumulate information to answer the clinical question. The search was conducted through collaboration with a health science librarian 


\section{REDUCING FALLS AMONG ACUTE REHABILITATION PATIENTS....8}

of the University of St. Augustine for Health Sciences (USAHS). The USAHS electronic resource databases was accessed to search for scholarly literature pertinent to the project.

The electronic search resulted in 10 relevant articles to support the PICOT question. The Cumulative Index to Nursing and Allied Health (CINAHL) Complete, Joanna Briggs Institute of EBP Database, PubMed, and Eric databases were searched through the USA Search engine. The specific keywords used in the literature searches were fall prevention intervention, acute admission, and brain injury patients. To avoid duplication, the inclusion criteria used for all the databases and articles contained the keywords, full text, date of publication years 2010-2019, English as the language, and peer-reviewed. The exclusion criteria included pediatric and ICU patients with additional diagnoses, such as psychiatric and suicidal tendencies. The search produced 952 records, but only 51 were eligible based on title and abstract review.

\section{Evidence Search Results and Evaluation}

With the four carefully chosen databases mentioned above, the search had initially produced a total of 51 research articles. The total search citations include 31 CINAHL citations, 15 PubMed citations, and five Eric citations, and these were reviewed and screened for the inclusion criteria. Additionally, a comprehensive search and synthesis of the literature was performed to understand the PICOT question's components better. To assist with the organization of the retrieved literature and relevant articles, an evidence table was created to include information such as Reference, Keywords, Research Method Design, Level, Quality Grade, Main Findings, Usefulness, and Level of Evidence. The literature review synthesis matrix aided in establishing and ensuring that the publication and articles were comprised of quality evidence and the most current information needed to create a patient safety intervention that supported the organization's EBP program (see Appendix A). To assist in evaluating the quality and critically 


\section{REDUCING FALLS AMONG ACUTE REHABILITATION PATIENTS....9}

appraise the evidence, step three of Melnyk and Fine-out Overholt's (2015) seven evidencepractice steps were used. The Strength of Recommendation Taxonomy (SORT) and the Preferred Reporting Items for Systematic Reviews and Meta-Analyses (PRISMA) were used to assess the quality of evidence and the level of findings (Bonnel \& Smith, 2018). The search result is included in the PRISMA table.

\section{Figure 1 PRISMA TABLE}
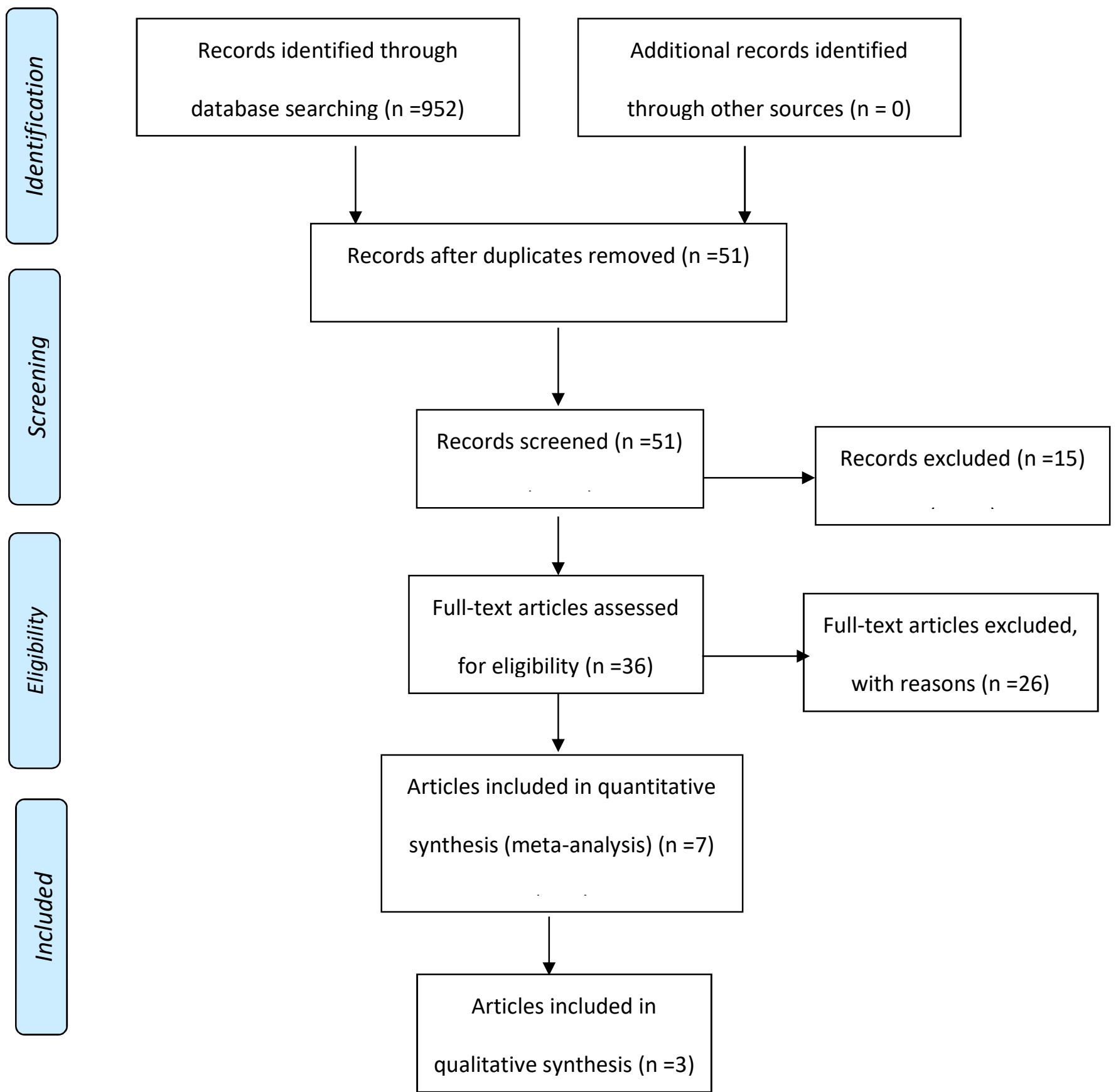
From: Moher D, Liberati A, Tetzlaff J, Altman DG, The PRISMA Group (2009). Preferred Reporting Items for Systematic Reviews and Meta-Analyses: The PRISMA Statement. PLoS Med 6(7): e1000097. doi:10.1371/journal.pmed1000097

\section{Themes from the Evidence}

The evidence evaluation table and synthesis consisted of 10 research studies relevant to the clinical question on fall prevention of patients seeking treatment at acute hospitals, which consisted of three qualitative and seven quantitative research articles (see Appendix A). All ten research articles explored falls and addressed interventions to improve patient safety. These articles explored the healthcare team, patients, and family members' perceptions regarding falls, causes, costs, and prevention efforts to determine any knowledge gaps in the implementation and sustenance of EBP fall prevention programs. The main themes identified in these articles included fall prevention intervention, population, patient outcomes, the role of a registered nurse (RN) in fall preventions, and communication.

\section{Fall Prevention Intervention}

Seven of the articles identified bed alarm use and VM as a primary intervention or as a component of a multifactorial fall prevention program. Baris and Seren Intepeler (2019) noted that falls are a complex event affected by multiple factors. The primary and the utmost noteworthy step in preventing patient falls was determining the causes of falls and the associated fall-prevention interventions. Successful implementation of a comprehensive fall prevention program stressed that bed alarms and fall risk signs were effective fall prevention interventions. Radecki, Reynolds, and Kara (2018) explored patients' perspectives in using bed alarms and gait belts as fall prevention interventions, and Wong et al. (2011) discussed the cost of serious fallrelated injuries for cognitively impaired patients.

\section{Population}


REDUCING FALLS AMONG ACUTE REHABILITATION PATIENTS....11

Three articles identified the inter-professional healthcare providers as having distinct and integral roles in the planning and implementing of a comprehensive and sustainable fall prevention program (Baris \& Seren Intepeler, 2019, \& Porter et al., 2018). All ten articles included patients 18 years of age and older, with one article focusing on older patients with cognitive impairment (Baris \& Seren Intepeler, 2019, Radecki, Reynolds, and Kara, 2018, \& Wong et al. 2011). Older adult patients with cognitive impairments have the highest risk for falls and related injuries. The selected population for this EBP project was essential in determining the impact of the proposed intervention as part of a fall prevention program.

\section{Patient Outcomes}

The use of bed alarms and fall risk signs could reduce fall events (Baris et al., 2019). The other six $(60 \%)$ articles noted the decline of falls and injuries related to falls using bed alarms and $\mathrm{VM}$ as prevention interventions. One can conclude that the appropriate use of bed alarms and VM positively impacted patient outcomes.

\section{Role of RN}

All ten articles identified various $\mathrm{RN}$ and Telesitter (VM technicians) roles in the comprehensive fall prevention program. These included completing the Morse Fall Scale (MFS) risk assessments promptly, ensuring the appropriate use of bed alarms, being a patient advocate, and developing a close RN-patient relationship to promote better patient understanding regarding the program fall evaluators leading the coordination of fall prevention strategies. One can conclude that RNs played a critical role in the fall prevention program. Two out of ten studies used unlicensed personnel in VM use (Sand-Jecklin et al., 2016; Votruba et al., 2016). Unlicensed personnel can reduce labor costs and allow more people to apply for a Telesitter or VM tech position. A wide variety of healthcare knowledge and skills is required to monitor many 
REDUCING FALLS AMONG ACUTE REHABILITATION PATIENTS....12

patients at once effectively. Organizations must develop practical training to introduce the VM tech to wide-ranging healthcare knowledge.

\section{Communication}

Six of the articles noted the importance of communication, including dissemination and sharing of essential healthcare providers' opinions and patient input as critical components of a comprehensive fall prevention program. Porter et al. (2018) noted that focused communication was vital to the thorough day-to-day preparation to improve patient safety and outcomes.

Fall events in the inpatient population are prevalent and a grave risk to patient safety. There has been an increase in demand to assess the most effective fall prevention interventions, such as increasing VM use to decrease hospital falls and related events. After reviewing the available EBP research studies, the most critical finding was that the VM method impacted fall prevention. All these studies have identified the reduction of fall-related events and injurious falls. Considering the evidence presented in this synthesis, one can conclude that the use of bed alarms and a VM system can improve patient safety and outcomes, either as primary interventions or part of a multifactorial part of a comprehensive fall prevention strategy. Four of ten studies had SORT 3, three had SORT 2, and three had SORT 1. VM supported consistent findings as a fall prevention strategy, and the recommendation at level A on the Strength of Recommendation Taxonomy was considered (Ebell, et al., 2004). See Appendix A for a Summary of Primary Research Evidence.

\section{Practice Recommendations}

A continuous effort is geared toward finding solutions to decrease the prevalence of inpatient falls. There has been an increased demand to assess the most effective interventions for a comprehensive EBP fall prevention program. The findings from the synthesis of the ten articles 
highlighted several factors that may impact the success and sustainability of an EBP fall prevention program, which follow.

\section{Fall as Team Responsibility for Staff and Patient and Family}

Fall prevention is team accountability, and it is vital to ensure patient and family engagement as full partners on the care team. Patient and family engagement enables patient decision-making and fosters family involvement in fall prevention. The evidence suggested a need for hospitals to have collaborative inter-professional training, explain role responsibilities, and develop consistent communication practices about patient-specific and standardized fall prevention approaches (Porter, 2018).

\section{Inter-professional Communication and Collaboration and Ensuring Stakeholder Buy-in}

Having an inter-professional collaborative approach has been deemed essential to the appropriate communication and development of timely actions related to falls. Organizations need to develop standardized protocols to support inter-professional team collaboration and corresponding planning related to an EBP fall prevention program (Porter, 2018). There was a correlation between the opinions of the stakeholder in successful fall prevention. Seeking these opinions will improve the effectiveness of fall prevention programs. It was recommended that the staff gather more comprehensive information from key stakeholders, including all healthcare professionals, patients, and patient family members (Baris et al., 2019).

\section{Use of Comprehensive Evidence-based Fall Prevention Program Interventions: Valid Fall}

\section{Risk Assessment, Bed Alarms, and Video Monitoring Technology}

Using valid risk assessments, such as a comprehensive fall risk assessment tool MFS and fall prevention procedures and guidelines for high-risk patients, improves nurse satisfaction. The use of bed alarms and patient sitters were effective fall prevention interventions. VM was one 
REDUCING FALLS AMONG ACUTE REHABILITATION PATIENTS....14

technology that may contribute to the observation and permit nurses to respond more quickly to prevent falls (Hardin, et al., 2013). Using the MFS Risk Assessment tool, the continuous use of bed alarms, and VM designed to recognize the patients who are at the higher risk of falling and signal nurses when the patients are about to get out of bed, can be essential components of the hospitals' comprehensive fall prevention programs (Ronald et al., 2012).

Based on the evidence outlined in this synthesis, it was recommended that fall prevention programs should include a VM system either as a primary intervention or part of a multifactorial comprehensive fall prevention strategy to improve patient safety and outcomes.

\section{Project Setting}

\section{Agency Description}

The project setting was a 150-bed inpatient rehabilitation center and part of the LACDHS. It is the second-largest municipal health department in the nation, caring for approximately 600,000 patients. The project agency cares for about 4,000 inpatients and conducts 85,000 outpatient visits annually with an average daily census of 140 patients. Rehabilitation services in stroke, spinal cord injury, brain injury, pediatrics, orthopedics, and diabetes management are provided. There are 75 acute Medical-Surgical beds and 75 acute inpatient rehabilitation beds, including 25 TBI beds. This facility is a renowned organization with state-of-the-art EBP treatments and accredited by TJC and the Commission on Accreditation of Rehabilitation Facilities (Rancho, 2019).

\section{Organization Mission and Vision}

The mission of the project's agency is to restore health, rebuild a life, and revitalize hope for persons with a life-changing illness, injury, or disability. Their vision statement is to be the 
REDUCING FALLS AMONG ACUTE REHABILITATION PATIENTS....15

recognized leader and valued partner in world-class neuroscience and rehabilitation (Rancho, 2019).

\section{Stakeholders}

The identified stakeholders for this project included patients, the Chief Nursing Officer (CNO), Chief Operations Officer, Chief Medical Officer, and Chief Information Officer (CIO), nursing team, including Nurse Managers, Information technology (IT) staff, Therapy staff, Physician-Patient Safety Officer, Safety Officer, Preceptor, and Housekeeping Supervisor. There were other representatives from the stakeholder group, such as Nursing Informatics and the Director of Nursing Education, identified as essential project team members. An organizational assessment was performed using organizational assessment tools to evaluate the organization's readiness, level of engagement, and support for the EBP project.

\section{Organization Assessment and SWOT Analysis}

Organizational assessment was vital to measure the readiness and level of stakeholder engagement of the change project and identify potential gaps before implementation. Regulatory assessment tools were used to determine the organizational preparedness for the planned practice change of implementing the continuous use of VM to decrease the prevalence of falls. The following three tools were used: Checklist to assess organizational readiness (CARI) for evidence-informed practice (Barwicjk, 2011), Institute for Healthcare Improvement (IHI) Capability Self-assessment tool (IHI, n.d.), and Organization's Cultural Profile Scale (Groysberg, Lee, Price, \& Cheng, 2018b). CARI was developed to review the stakeholders' readiness for EBP implementation (Barwicjk, 2011). In using the CARI tool, the senior leadership and organizational capacity relative to financial resources showed the highest readiness and strengths. These results were consistent with the values and vision of Executive Leadership. 
However, staff training and staff capacity rated "some way to go" to the change practice implementation readiness and need additional attention.

Similarly, the IHI Improvement Capability self-assessment tool was used, and the leadership appraised as exemplary for active engagement and set goals and priorities for its improvement activities. The capability of the organization to demonstrate measurable improvement across all departments and areas was still developing. Synthesis of the findings from using these three tools showed exemplary organizational senior leadership and readiness to support implementing the continuous use of VM for fall prevention. These tools were consistent in recognizing gaps and areas that need the most focus: staff training and the capability to sustain improvement for the EBP projects. Additionally, a SWOT analysis was performed to identify the organization's strengths, weaknesses, opportunities, and threats, noted in Figure 2.

\section{Figure 2 SWOT ANALYSIS}

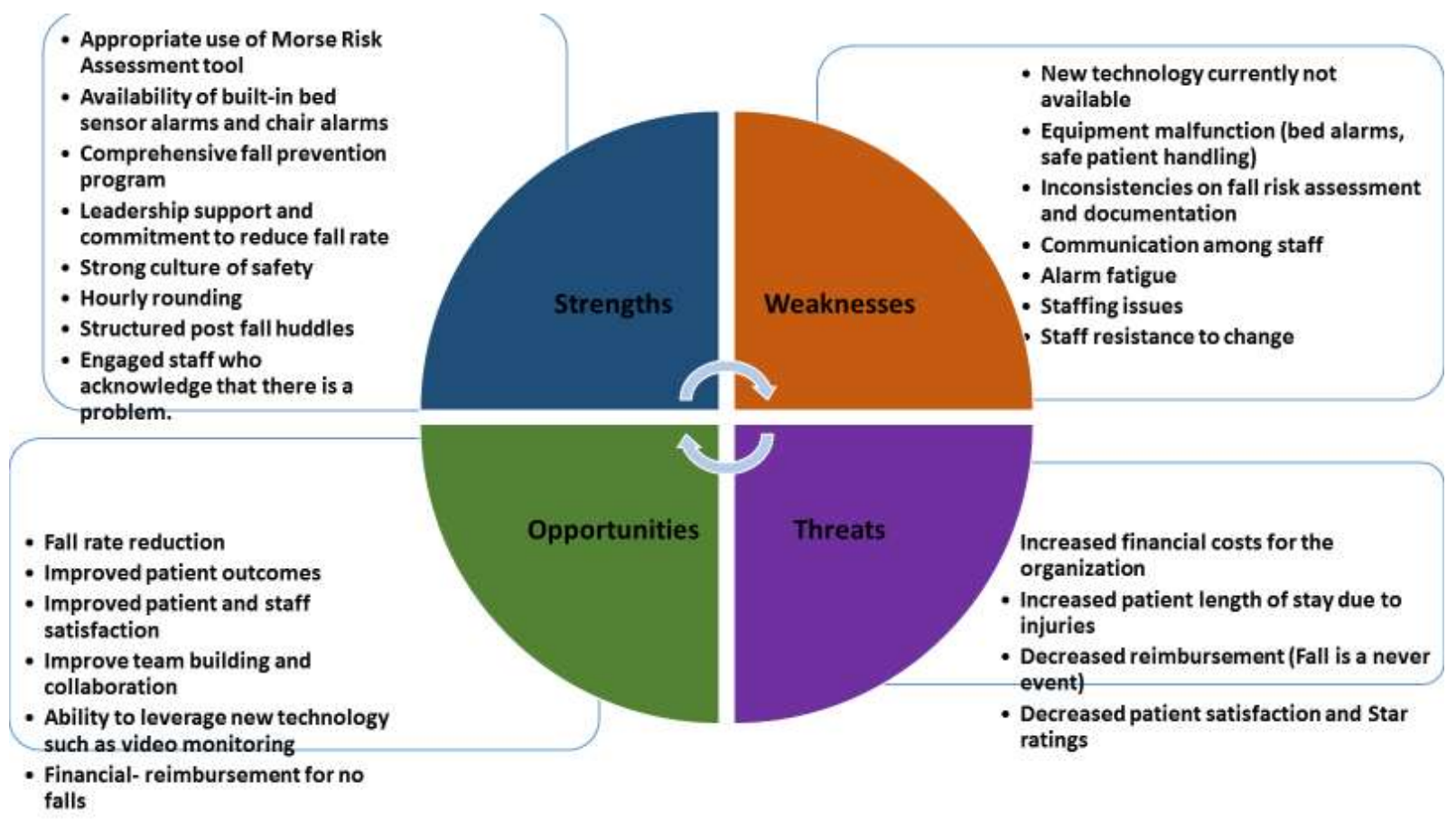

Some of the strengths identified included strong leadership support and commitment to reducing falls, the organization having a comprehensive fall prevention program, the 
organization's strong culture of safety, the appropriate use of the MFS Risk assessment tool, and engaged staff who acknowledge that falls were a problem. The weaknesses identified included staffing issues, alarm fatigue, equipment malfunction, bed alarms, inconsistencies in fall risk assessment and documentation, and the new technology (VM) not available. The opportunities identified included the potential for a fall rate reduction, improved patient outcomes, improved patient, and staff satisfaction, improved financial reimbursement, and the ability to leverage new technology within the organization. The threats and the impetus for the EBP change project proposal included increased economic costs for the organization, increased length of stay, decreased reimbursement, poor patient outcomes, and decreased patient satisfaction. A review of the SWOT analysis findings showed the evidence of the structural and process measures that support this EBP project's implementation.

\section{Project Overview}

\section{Project Short-term and Long-term Goals}

The short-term objective of the project was focused on the immediate improvement in patient safety, focusing on decreasing fall events in the adult TBI unit within six weeks of implementing the proposed VM intervention. The long-term objective was focused on the sustainability of reducing fall rates after the initial project implementation and spreading the EBP project throughout the organization. These goals and objectives were in congruence with the agency's mission, vision, and strategic priorities.

\section{Project Risk and Unintended Consequences}

A risk assessment was performed for the project to address some of the potential risks and consequences. All identified risks included technological, privacy and security, staffing, and patient-related issues. The organization hired four full-time equivalent staff to function as VM 
technicians. Several nursing attendants were also cross-trained to serve as VM technicians when there was a need and when the dedicated team was not available. One of the potential unintended consequences was the possible refusal of patients. The issue related to patient refusal and noncompliance were mitigated by ensuring patients and families received training about the VM intervention. The patient educational handouts (see Appendix B) were provided to the appropriate patient and family before initiation of intervention. One of the potential unintended benefits of this project was the cost savings associated with the costs for private sitters and savings related to the avoidance of increasing length of stay resulting from falls. The increase in patient and staff satisfaction was another potential unexpected benefit.

\section{Project Plan (Method)}

The EBP project aimed to decrease the prevalence of falls among acute rehabilitation patients by $10 \%$ by implementing a VM system for surveillance of TBI patients who were at risk for falls and alert staff to provide early intervention to prevent the fall. All patients were assessed upon admission and every shift for fall risk using a comprehensive and valid fall risk assessment tool MFS (see Appendix C). The MFS was a fast and simple process of evaluating a patient's probability of falling. The MFS assessment tool consisted of six variables that are quick and easy to score and has been shown to have predictive validity and interrater reliability. The MFS is used widely in acute care settings, both in the hospital and long-term care inpatient settings (MFS, n.d.). Patients with a score of 25 or more were classified as high risk for falls. The permission to adapt the MFS was received on 09/22/2020 (MFS, n.d). Before the project implementation, the facility only used bed alarms. The project manager (PM) worked with the facility leadership on the procurement of a VM system implemented during this EBP project. The adult TBI patients who met inclusion criteria were placed on the VM (AVASURE 
TeleSitter). During the implementation process, a VM system's use allowed the monitoring of up to 12 patients who were at risk for falls by a VM tech. The VM system had the capability that allowed the monitor technicians to communicate directly with the patient to refocus the patient and notify the patient's nurse of the patient's activity for immediate intervention, which may have prevented the fall event. The intervention entailed the deployment and use of VMs for use with brain injury patients in the TBI with the VM tech observing patient's activities in real-time. Feasibility, cost, and impact of the intervention on the project were evaluated. The planned project of implementing a VM system to reduce the prevalence of falls was an EBP project aimed to improve the current fall prevention program process. A step-by-step process used to implement this project was presented using a project timeline describing four phases taken: (1) project planning, (2) logistical planning, (3) project implementation, and (4) data collection and analysis.

Activities under project planning included meeting with the preceptor, identifying issues, gaps, and staffing needs, review and synthesizing literature, preparing a project proposal, discussing with leadership regarding the proposal, identification of key stakeholders, identification of nursing resources and provider support, development of policy and procedures, identification of equipment requests, identification go-live date, and the acquisition of facility Evidence-Based Practice Committee support. The team initiated this process in January of 2020. Activities under logistical planning included the identification of the vendor for VM system, assessment of technical needs after reviewing specification needs, assignment of the IT staff to assess hospital readiness, security and privacy needs, validated documentation platform in electronic health records (EHR) were ready, conducted testing for connectivity and remote access, established downtime procedures, coordinated weekly vendor and project team 


\section{REDUCING FALLS AMONG ACUTE REHABILITATION PATIENTS....20}

communication teleconferences, and coordinated go-live implementation. Other steps included defining the roles and responsibilities of the unit nursing staff, the house supervisors, and the monitor technicians. The development of a patient and family awareness process, establishment of a cleaning process of the VM devices, creation of the admission and discontinuation workflow, creation of policies and procedures which defined the inclusion and exclusion criteria were performed. It was important to develop a nursing staffing plan for the success of the VM system. This included hiring of the monitor technicians, requesting for purchase approval, identifying a storage location for devices when not in use, creating a workflow for the transport of devices from storage, establishing a process for tracking VM devices, and defining change of shift communication for unit nursing staff and monitoring technicians. The procurement of the equipment, vendor training, and the hiring of monitor technicians were completed in September 2020.

Activities under project implementation included confirmation with facility approval, USAHS approval, budget approval, set project meetings weekly to track progress and making the necessary adjustments, identification of training needs of new and existing staff on the TBI unit, supervisor, and newly hired VM technicians, and the development of an educational plan. The project team offered an education plan for the clinical champions and patient care team regarding the project change proposal's background and VM implementation, such as the VM tech. The training information was communicated using educational flyers to train and orient the appropriate staff (see Appendix D). The evidence of training was monitored through sign-in rosters (see Appendix E). Copies of the PowerPoint presentation were provided during training sessions (see Appendix F and G) as handouts to augment the participant's learning. A copy of the 


\section{REDUCING FALLS AMONG ACUTE REHABILITATION PATIENTS....21}

patient education handout was also included to increase the participant's understanding. The project team initiated the proposed implementation for the selected TBI unit in November 2020.

Activities under data collection and analysis included information on the patients who received the VM intervention, such as patients who were admitted to the TBI unit and had a diagnosis of TBI. High risk for falling was determined by but not limited to, such things as Fall risk assessment tool/score of 25 on the MFS, history of falls, previous falls during their stay, medical conditions requiring medical safety restraints, metabolic disorder, central nervous system disorder, hypoxia, lack of muscle control, medication side effects, dementia, neutropenic patients, deconditioned patients with behaviors, such as physically harmful actions, wandering, climbing, pulling at tubes/drains, restlessness, and other behavioral issues, and exacerbated behavioral symptoms. The exclusion criteria include patients having homicide and suicide ideations described in (see Appendix H), and those patients who were on a bed alarm as a fall prevention modality. For this EBP project, quantitative data collection was conducted in a structured environment (hospital). The data compilation tool helped determine the impact of using VM as an intervention for the identified nursing unit and fall events using bed alarms. The implementation process started with collecting data for the number of falls, VM use rates, and bed alarm use rates created for the TBI unit and other rehabilitation units. The data were retrieved using a standardized data compilation tool (see Appendix I), which captured elements such as data from hospital finance (diagnosis), Safety Intelligence (SI) reports, post-fall huddles, as well as the hospital's electronic medical record (fall risk documentation and type of intervention used), the VM system dashboard as the primary data source on VM use, and bed alarm use. The EHR was reviewed to determine patients admitted to the identified rehabilitation unit with a TBI diagnosis, documented fall risk assessments using MFS, and eligibility for VM 
system use as an intervention. Fall events were gathered from the SI reports for the TBI unit of patients on the VM system daily. Data related to the number of falls were collected on patients using VM system intervention and compared the number of patient falls on the other rehabilitation units, who only used bed alarms as the fall prevention intervention. VM utilization was collected and assessed electronically by the Avasure TeleSitter system, which also provided several reports about the VM system start and end-use per patient and any fall events. Successful implementation of this EBP project was determined by achieving a $10 \%$ reduction among patient falls using the VM versus those using the standard bed alarms.

\section{Iowa Model and Lewin Change Model}

The Iowa Model of EBP was selected for this EBP project to guide the practice change and provide a step-by-step process for implementing a change (Brown, 2014). The initial step in the Iowa Model was to identify a problem-focused trigger, such as patient falls. Step two was to evaluate if the problems were a priority for the organization (Brown, 2014). For this EBP project, quality resource management and risk management data revealed an opportunity to reduce the current fall rate and dangerous fall prevalence. Fall prevention was a priority for the organization; therefore, leadership and organizational stakeholders supported seeking additional interventions to augment the agency's comprehensive fall prevention program. The next step was to form a team to help develop, assess, and implement the EBP change. The project team consisted of the PM, project advisor, nurse manager, nurse supervisor, nursing staff, and education department leader. Other members included an inter-professional collaborative team from IT, quality management, and analytic data staff who helped evaluate the implementation of a VM system for fall prevention. 
REDUCING FALLS AMONG ACUTE REHABILITATION PATIENTS....23

The next step was to compile relevant evidence related to the proposed practice change, which consisted of developing the appropriate PICOT question and performing the proper literature search to determine if enough evidence existed to implement the proposed practice change. The next step was implementing the intervention into a practice change (Brown, 2014). For this proposed change, the organization implemented the new VM system in the TBI unit. After determining the change was suitable for clinical practice implementation, the final step was evaluating the change (Brown, 2014).

In theoretical underpinnings for change, Lewin's theory of change was another conceptual model relevant to this project. Lewin's model is a valuable framework for understanding its change process (Shirey, 2013). Lewin hypothesized a three-stage model of change known as the unfreezing-change-refreeze model. The unfreezing stage necessitates the rejection and replacement of prior learning. For the current fall prevention program, private sitters, bed alarms, and hourly rounding, the staff needed to accept the VM system's inclusion in the project were included. This stage required the organization's collaborative team to change the way they reasoned and behaved related to the new proposed change (Cummings, Bridgman, \& Brown, 2016). The Lewin change theoretical framework was appropriate for planned change and ample time and stability to effect a change.

\section{Schedule of Activities}

A Gantt chart was developed to foresee the project timeline, steps, and progress (see Appendix J). The step-by-step process used to implement this project used a timeline which included project planning, logistical planning, project implementation, and data collection. Some of the benefits of a Gantt chart included determining all necessary tasks, timeline, when the tasks need to be completed, and progress (Sharon \& Dori, 2017). Using a Gantt chart helped define the 
REDUCING FALLS AMONG ACUTE REHABILITATION PATIENTS....24

parts or implementation stages of the proposed change project, the delineation of related activities to be taken, the projected time needed for each event, and itemized sequential activities carried out and completed (Harris, et al., 2018).

\section{Project Budget}

The development of successful projects needed a comprehensive budget that results in an achievable goal. A project budget was created based on an accurate approximation of all costs required from start to completion. According to Harris et al. (2018), project budgets must be flexible using accessible sources to avoid unnecessary costs. A typical project budget includes expenses for staff labor, materials and procurement, ongoing operation costs, other direct costs such as travel and education, and indirect costs that support the project, such as building expenses (Harris et al., 2018). This proposed change project itemized labor, service, and supplies for implementing the VM system (see Appendix K). Additional costs incurred for the project to the facility's operational budget, including ongoing staff education and VM equipment maintenance were added.

\section{Role of the DNP Student}

The DNP student assumed the role of the PM in this EBP project. The PM was responsible for compiling and evaluating the literature related to fall prevention within this organization, developing the PICOT question, and developing the project proposal. Additionally, the PM leveraged knowledge and expertise of the preceptor, who also holds the CNO's position in the whole project management process. The PM assessed the facility's current fall management process before implementation and was responsible for evaluating the current fall prevention strategies for effectiveness and identifying improvement opportunities for preventing falls and injurious falls within the proposed organization. Lastly, the DNP student assisted the 
REDUCING FALLS AMONG ACUTE REHABILITATION PATIENTS....25

facility by implementing the proposed EBP project using new technology and assessing the EBP project's impact in decreasing the number of falls on the TBI unit, improving patient satisfaction, and enhancing patient outcomes, and increasing patient safety. As the PM, the DNP student oversaw this project, coordinated, managed the data collection, coordinated the EBP education program with the education department, collaborated with IT for the data retrieval, and collected and analyzed the findings.

\section{Result}

The focus of this project aimed to determine whether real-time VM surveillance would decrease the prevalence of falls in TBI patients on a rehabilitation unit. The premise of the project was that potential fall situations could be prevented or reduced by early intervention in the form of VM technicians verbally refocusing patients and quickly alerting staff. The organization used the MFS, a comprehensive fall risk assessment tool, to identify moderate and high fall risk patients. Sixteen patients met the inclusion criteria to participate in the project. The VM surveillance impact was evaluated by comparing the number of falls and fall rates pre- and post-project implementation (see Figure 3). Results from descriptive statistics and calculation of percent changes were used to evaluate the use of VM in decreasing falls and fall rates in TBI patients on a rehabilitation unit.

\section{Evaluation Design}

Frequencies, means, and percentages were calculated using descriptive analysis.

Intellectus statistics software was used to calculate descriptive statistics on demographic data and MFS total scores. The VM surveillance effectiveness was determined by comparing the fall rates per 1,000 patient days before and after the project implementation, which described the 
REDUCING FALLS AMONG ACUTE REHABILITATION PATIENTS....26

percentage in fall difference. Data for the hospital and rehabilitation unit was used for the comparison fall rates.

\section{Data Collection}

Demographic data was collected on patients who met the inclusion criteria for the project. Demographic information consisted of age, gender, race/ethnicity, MSF fall risks, and MFS total score. Fall risk assessment information was collected on admission and every shift by the nursing staff using the MFS. Data on the number of falls, VM use rates, and bed alarm use rates were collected prior to the start of the project implementation for the TBI unit and other rehabilitation units. The data were retrieved using a standardized data compilation form, which captured elements such as data from hospital finance (diagnosis), hospital occurrence reports (SI), postfall huddles, hospital's electronic medical record (fall risk documentation and type of intervention used) and the VM system dashboard as the primary data source on VM use and bed alarm use. Data security was assured by adherence to HIPAA regulations and hospital privacy regulations. VM technicians were trained and competent specific to privacy and security components. Providing secure data storage was essential to the integrity and security of the project and the safeguard of patient health information. The data were stored in a passwordprotected dedicated shared folder that the PM managed. To address the possible missing data, all the data and workflow processes were reviewed. The inclusion and exclusion criteria were reviewed by staff to include all patients meeting the VM process.

\section{Data Analysis}

During the data collection period from November 1, 2020, to December 15, 2020, sixteen patients met the inclusion criteria and were placed on VM on the TBI unit. The majority were male (75\%), with most identified as Hispanic (56\%), followed by Black (25\%) and non-Hispanic 
White (19\%). The mean age of the 16 patients was 45 years old, with age brackets consisting of $20-30$ years (31\%), 31-40 years (25\%), 41-50 years $(0 \%), 51-60$ years $(18 \%)$, and $>60(25 \%)$.

Only patients who scored high fall risk $(87.5 \%)$ and moderate fall risk on the MFS (12.5\%) were included in the project. Scores on the MFS score ranged from a minimum of 25 to a maximum of $60(M=42.19)$ with a standard deviation of 11.25 .

Data showed that the average fall rate of the hospital from January 2019 to October 2020, before VM implementation, was 2.5 per 1,000 inpatient days. After VM implementation (November 1, 2020, to December 15, 2020), the falls rate decreased to 1.38 per 1,000 inpatient days. This finding was a 49\% hospital fall rate reduction. Data showed that the rehabilitation average fall rate during January 2019 to October 2020, before VM implementation, was 3.11 per 1,000 inpatient days. After VM implementation (November 1, 2020, to December 15, 2020), the fall rates decreased to 1.09 per 1,000 inpatient days. This change was a $65 \%$ decrease in the fall rate. The average fall rate in the TBI unit before the VM was 0.59 per 1,000 inpatient days. After VM implementation, that there were zero patient falls in the TBI unit or a $100 \%$ reduction in TBI fall rate (see Figure 3).

\section{Figure 3 Fall Data for TBI, Hospital and Rehabilitation Units per 1,000 patient days}

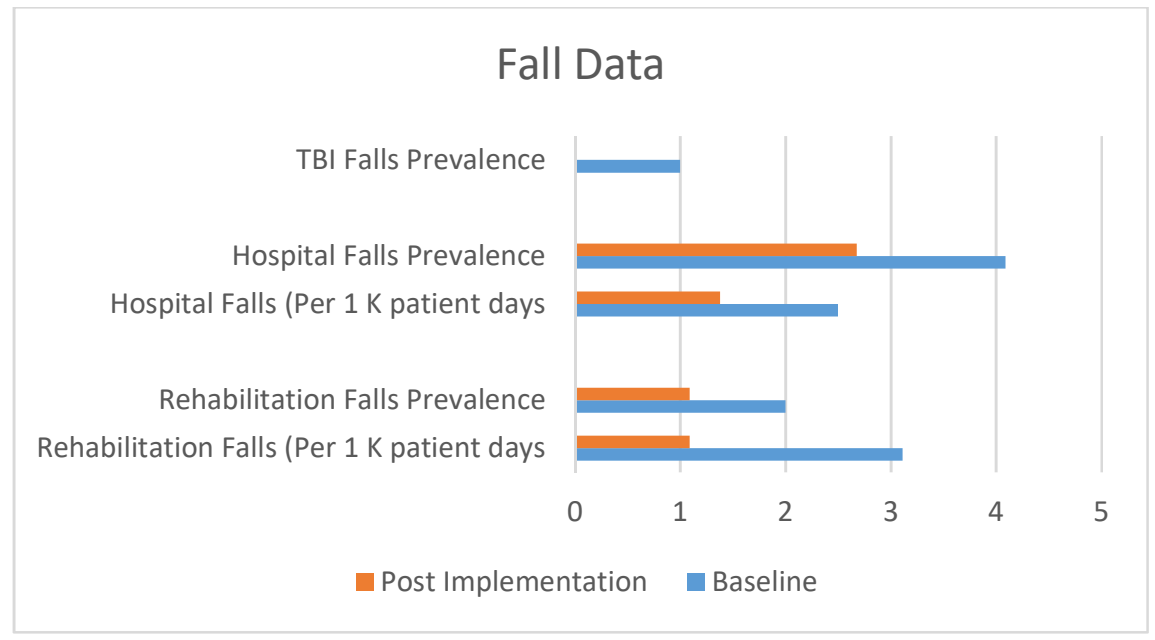


REDUCING FALLS AMONG ACUTE REHABILITATION PATIENTS....28

\section{Project Significance}

This clinical project demonstrated the evidence and support for the use of live VM surveillance as an intervention to decrease fall rates on a TBI unit and improve patient safety. The PICOT outcome of the project was to reduce the hospital falls by $10 \%$. The intervention achieved a $49 \%$ reduction in the hospital fall rate per 1,000 patient days and $65 \%$ in the rehabilitation fall rate per 1,000 patient days after implementing the project. As a result, this EBP project was recognized as improving clinical care provided by the organization. All categories of measures, including outcomes, process, balancing, financial, and sustainability identifying benchmarks for each measurement, are displayed (see Appendix L). Quality measures were used to assess if the data obtained in the EBP was clinically significant in the promotion of fall reduction and based on this data, it was shown that an overall decrease in falls for the hospital system occurred. Prevention of falls can avert additional patients suffering increased length of stay, liability, and lack of reimbursement. In summary, the EBP supported real-time VM surveillance in the rehabilitation and TBI setting. Additionally, the organization will evaluate the application of the EBP throughout other locations in the hospital.

\section{Impact}

There is a growing necessity to implement evidence-based approaches that positively impact healthcare outcomes and address the global issue of fall reduction and prevention. Nearly $20 \%$ of hospitalized patients have experienced a fall event that affected them physically, emotionally, financially, and mentally; thus, they experienced a suboptimal quality of life experience. The EBP found the development and implementation of a new fall prevention program using VM surveillance to be clinically significant in preventing falls in patients on a TBI unit. The project answered the clinical question and practice problem by demonstrating its 
REDUCING FALLS AMONG ACUTE REHABILITATION PATIENTS....29

impact on the hospital fall prevalence, fall rate, staff, and patient compliance within the organization. The EBP compared the impact of the VM intervention to prior practice (use of bed alarms) through data collection pre-and post-implementation of the EBP intervention. During the 6-week implementation phase, evidence supported a 49\% reduction in the hospital fall rate per 1,000 patient days, a $65 \%$ in the rehabilitation fall rate per 1,000 patient days after implementing the project, $100 \%$ reduction in TBI fall rate per 1,000 patient days, and a $30 \%$ reduction in cost for 1:1 sitter and was considered a clinical improvement.

The future implication of the project will be expanding the use of the VM system for the entire organization. The organization purchased an additional eight VM monitors and another 49-inch TV monitor. The organization plans to start using 16 of the 20 VM monitors in all Rehabilitation and Medical-Surgical areas three months after the EBP implementation. Additionally, new VM staff were hired and completed the appropriate training. The limitation of the full hospital-wide implementation of the project was related to space. The previous area only allowed the use of one 49-inch monitor and two VM tech seating spaces. After addressing the space issue, the organization plans to use the 20 video monitors hospital-wide with two large monitors and the appropriate VM technicians. The Nursing Informatics Department maintained the project sustainability as the organization charged the nursing informatics staff with ongoing data collection and assessing the effectiveness hospital-wide.

\section{Dissemination}

Communication of relevant findings from an EBP project is a professional responsibility and is essential for improving patient outcomes (Oermann, 2018). Findings from this EBP project will focus on communication within the organization, professional groups, and scholarly publications. Results will be presented to the hospital administration at the Executive Council 
REDUCING FALLS AMONG ACUTE REHABILITATION PATIENTS....30

and to committees with a heavy representation of staff nurses, such the Interdisciplinary Falls Committee, Nursing Executive Council, Nurse Certification Tea, Hospital Management Staff meeting, Hospital Quality, Risk and Patient Safety Committee, Nursing Management and Operations Council, and the Quality Safety Outcome and Magnet Councils. Presentations will occur at regularly scheduled committee meeting times in a hospital conference room using a 20minute PowerPoint presentation and handouts describing the intervention and results. Flyers with project results will be disseminated to all hospital staff via email and a one-page flyer posted on the hospital intranet. The EBP Council committee of hospital interdisciplinary experts will review the project findings, who use a peer review process to recommend practice changes. Regional poster presentations will occur at the Los Angeles County Department of Health Services at the Annual Patient Safety Conference and the Patient Safety Conference of the local chapter of the Association of Rehabilitation Nurses. Posters will be submitted to National groups such as Collaborative Alliance for Nursing Outcomes and American Nurses Credentialing Center Magnet Conference. A manuscript will be submitted to the Quality Management in Healthcare Journal, due to its high impact and acceptance of evidence-based projects. The hospital EBP Council committee of interdisciplinary experts will peer review the manuscript and provide publication assistance.

\section{Conclusion}

Falls have a high prevalence in the hospital setting, causing a severe risk to patient safety, particularly among the elderly (Ronald et al., 2012). Inpatient falls remain the leading cause of adverse events occurring in hospitals worldwide (Quigley \& White, 2013). Studies of falls on rehabilitation units have usually reported a relatively high rate of falls and $12.5 \%$ of patients admitted to an inpatient rehabilitation unit fell at least once while on the unit (Forrest et al., 


\section{REDUCING FALLS AMONG ACUTE REHABILITATION PATIENTS....31}

2012). TBI rehabilitation patients with a severe brain injury categorized by multisystem impairments are at an increased risk of falling. Some common fall risk factors, such as age, sex, medication quantity and type, and prior events, may be associated with falls in this population (McKechnie, 2018). The purpose of this EBP project was to decrease the prevalence of falls among acute rehabilitation patients by $10 \%$ through the implementation of a VM system for surveillance of TBI patients who are at risk for falls. The premise of the project was that potential fall situations could be prevented or reduced by early intervention in the form of VM technicians verbally refocusing patients and quickly alerting staff to fall situations. 


\section{References}

Adorno, M., Garbee, D., \& Marix, M. L. (2016). Improving literature searches. clinical nurse specialist: The Journal for Advanced Nursing Practice, 30(2), 74-80. https://doi.org/10.1097/NUR.0000000000000187

Baris, V. K., \& Seren Intepeler, S. (2019). Views of key stakeholders on the causes of patient falls and prevention interventions: A qualitative study using the international classification of functioning, disability, and health. Journal of Clinical Nursing, (3-4), 615. http://doi.org/10.1097/NCQ.0000000000000054

Barwicjk, M.A. (2011). Checklist to assess organizational readiness (CARI) for EIP implementation. Retrieved from http://www.effectiveservices.org/downloads/Checklist to Assess_Organisational_Readin ess for Implementation.pdf.

Bonnel, W., \& Smith, K. (2018). Proposal writing for clinical nursing and DNP projects (2nd ed.). New York, NY: Springer Publishing Company.

Brown, C. G. (2014). The Iowa model of evidence-based practice to promote quality care: An illustrated example in oncology nursing. Clinical Journal of Oncology Nursing, 18(2), 157-159. https://doi.org/10.1188/14.CJON.157-159

California Department of Public Health. (CDPH, n.d.). Older adult falls prevention program. Retrieved from https://www.cdph.ca.gov/Programs/CCDPHP/DCDIC/SACB/Pages/OlderAdultFallsPrev entionProgram.aspx 
REDUCING FALLS AMONG ACUTE REHABILITATION PATIENTS....33

Center for Medicare and Medicaid Services. (CMS, 2011). Hospital acquired conditions.

Retrieved September 11, 2011 from https://www.cms.gov/hospitalacqcond/06 hospitalacquired conditions.asp

Cox, J., Thomas-Hawkins, C., Pajarillo, E., DeGennaro, S., Cadmus, E., \& Martinez, M. (2015). Factors associated with falls in hospitalized adult patients. Applied Nursing Research, 28(2), 78-82. https://doi.org/10.1016/j.apnr.2014.12.003

Cummings, S., Bridgman, T., \& Brown, K. G. (2016). Unfreezing change as three steps: Rethinking Kurt Lewin's legacy for change management. Human Relations, 69(1), 3360. https://doi.org/10.1177/0018726715577707

Donaldson M.S. (2008) An overview of to err is human: Re-emphasizing the message of patient safety. In Patient Safety and Quality: An Evidence-Based Handbook for Nurses: Vol. 1 (Hughs R.G., ed.), Agency for Healthcare Research and Quality, Rockville, MD, pp. 3745.

Dykes, P. C., Carroll, D. L., Hurley, A., Lipsitz, S., Benoit, A., Chang, F., Meltzer, S., Tsurikova, R., Zuyov, L., \& Middleton, B. (2010). Fall prevention in acute care hospitals: A randomized trial. JAMA, 304(17), 1912-1918. https://doi.org/10.1001/jama.2010.1567

Dykes, P. C., Adelman, J., Adkison, L., Bogaisky, M., Carroll, D. L., Carter, E., Duckworth, M., ... \& Yu, S. P. (2018). Preventing falls in hospitalized patients: Engage patients and families in a three-step prevention process to reduce the risk of falls. American Nurse Today, 13(9), 8-13.

Ebell, M., Siwek, J., Weiss, B., Woolf, S., Susman, J., Ewigman, B. \& Bowman, M (2004). Strength of Recommendation Taxonomy (SORT): A patient-centered approach to grading evidence in the medical literature. American Family Physicians, 69(3), 549-556. 
REDUCING FALLS AMONG ACUTE REHABILITATION PATIENTS....34

Forrest, G., Huss, S., Patel, V., Jeffries, J., Myers, D., Barber, C., \& Kosier, M. (2012). Falls on an inpatient rehabilitation unit: Risk Assessment and prevention. Rehabilitation Nursing, 2,56 .

Grigorovich, A. \& Kontos, P. (2020). Towards responsible implementation of monitoring technologies in institutional care. The Gerontologist, 60(7), 1194-1201, https://doi.org/10.1093/geront/gnz190

Groysberg, B., Lee, J., Price, J., \& Cheng, J-Y. (2018b, January-February). What's your organization's cultural profile? Harvard Business Review, 53.

Hardin, S. R., Dienemann, J., Rudisill, P., \& Mills, K. K. (2013). Inpatient fall prevention: Use of in-room Webcams. Journal of Patient Safety, 9(1), 29-35. https://doi.org/10.1097/PTS.0b013e3182753e4f

Harris, J. L., Roussel, L., Dearman, C., \& Thomas, P. L. (2018). Project planning and management: A guide for nurses and interprofessional teams. Burlington, MA: Jones \& Bartlett Learning.

Hester, A. L., Tsai, P., Rettiganti, M. \& Mitchell, A. (2016). CE. Predicting injurious falls in the hospital setting: Implications for practice, American Journal of Nursing, 116(9), 24-31. http://doi.org/10.1097/01.NAJ.0000494688.10004.85

Hodo, A., Munsterman, E., \& Newomb, P. (2018). Factors associated with falls among hospital inpatients. Nursing Management Journal, 38-44. https://doi.org/10.1097/01.NUMA.0000547259.22709.82

IHI improvement capability self-assessment tool. IHI (n.d.). Retrieved from http://app.ihi.org/FacultyDocuments/Events/Event-2354/Presentation-9119/Document7406/L2_Improvement_Tool.pdf 
REDUCING FALLS AMONG ACUTE REHABILITATION PATIENTS....35

Intellectus Statistics [Online computer software]. (2020). Intellectus Statistics. https://analyze.intellectusstatistics.com/

Sand-Jecklin, K., Johnson, J., Tringhese, A., Daniels, C., \& White, F. (2019). Video monitoring for fall prevention and patient safety: process evaluation and improvement. Journal of Nursing Care Quality, 34(2), 145.

Los Angeles County Department of Public Health http://publichealth.lacounty.gov/ivpp/injury topics/falls/LA\%20County\%20Hospitalizati on $\% 20$ Report $\% 202008 \% 20-\% 20$ Falls.pdf

Maas, A., \& Manley, G. (2013). Traumatic brain injury an international knowledge-based approach. Journal of the American Medical Association, 310(5), 473-474.

Manchester, Gray-Miceli, Metcalf, Paolini, Napier, Coogle, \& Owens, (2014). Facilitating Lewin's change model with collaborative evaluation in promoting evidence-based practices of health professionals. Evaluation and Program Planning, 47, 82-90. https://doi.org/10.1016/j.evalprogplan.2014.08.007

McKechnie, D. (2018). Development of a falls risk screening tool in a traumatic brain injury rehabilitation population: A two-phased project. Journal of the Australasian Rehabilitation Nurses' Association (JARNA), 21(1), 22-24.

Morse Fall Scale. MFS (n.d.). https://networkofcare.org/library/Morse\%20Fall\%20Scale.pdf National Database of Nursing Quality Indicators. NDNQI (2019). Retrieved from https://www.nm.org/about-us/quality/quality-measures/sites-of-care/northwestern- 
memorial-hospital/national-comparisons/ndnqi-national-database-of-nursing-quality$\underline{\text { indicators }}$

Oermann, M. H. (2018). Writing publishable review, research, quality improvement, and evidence-based practice manuscripts. Nursing Economics, 36(6), 268-275.

Porter, R. B., Cullen, L., Farrington, M., Matthews, G., \& Tucker, S. (2018). CE: Original research: Exploring clinicians' perceptions about sustaining an evidence-based fall prevention program. American Journal of Nursing, (5), 24.

http://doi.org/10.1097/01.NAJ.0000532806.35972.29

Preferred Reporting Items for Systematic Reviews and Meta-Analyses. PRISMA (n.d.). www.prisma-statement.org.

Quigley, P. A., \& White, S. V. (2013). Hospital-based fall program measurement and improvement in high reliability organizations. Online Journal of Issues in Nursing, 18(2), 1. https://doi.org/10.3912/OJIN.Vol18No02Man05

Radecki, B., Reynolds, S., \& Kara, A. (2018). Original article: Inpatient fall prevention from the patient's perspective: A qualitative study. Applied Nursing Research, 43, 114-119. http://doi.org/10.1016/j.apnr.2018.08.001

Rancho Los Amigos National Rehabilitation Center. (Rancho, n.d.). Los Angeles County Department of Health Services-Rancho Los Amigos Home. Retrieved from http://dhs.lacounty.gov/wps/portal/dhs/rancho

Ronald I., S., A. Michelle, C., Lorraine C., M., Teresa M., W., Minzhao, L., Michael J., D., ... Stephen T., M. (2012). Effects of an intervention to increase bed alarm use to prevent 
REDUCING FALLS AMONG ACUTE REHABILITATION PATIENTS....37

falls in hospitalized patients: A cluster randomized trial. Annals of Internal Medicine, (10), 692 .

Schwenk, M., Lauenroth, A., Stock, C., Moreno, R. R., Oster, P., McHugh, G., Todd, C., \& Hauer, K. (2012). Definitions and methods of measuring and reporting on injurious falls randomized controlled fall prevention trials: A systematic review. BMC Medical Research Methodology, 12, 50. https://doi.org/10.1186/1471-2288-12-50

Sharon, A., \& Dori, D. (2017). Model-based project-product lifecycle management and Gantt chart models: A comparative study. Systems Engineering, 20(5), 447-466. https://doi.org/10.1002/sys.21407

Shirey, M. R. (2013). Strategic leadership for organizational change. Lewin's theory of planned change as a strategic resource. Journal of Nursing Administration, 43(2), 69-72. https://doi.org/10.1097/NNA.0b013e31827f20a9

Soncrant, C., Neily, J., Bulat, T., \& Mills, P. D. (2019). Recommendations for fall-related injury prevention: A 1-year review of fall-related root cause analyses in the Veterans health administration. Journal of Nursing Care Quality, 35(1), 77.

Vanderberg, A., van Beijnum, B., Overdevest, V., Capzuti, E., Johnson, T. (2017). US and Dutch nurse experiences with fall prevention technology within nursing home environment and workflow: A qualitative study. Geriatric Nursing 38, 276-282. http://dx.doi.org/10.1016/j.gerinurse.2016.11.005

Votruba, L., Graham, B., Wisinski, J., \& Syed, A. (2016). Video monitoring to reduce falls and patient companion costs for adult inpatients. Nursing Economics 34(4), 185-189.

World Health Organization (WHO, 2018). Key fats on falls. Retrieved from https://www.who.int/news-room/fact-sheets/detail/falls 
Wong, C., A., Recktenwald, A., J., Jones, M., L., Waterman, B., M., Bollini, M., L., \& Dunagan, W., Claiborne. (2011). The cost of serious fall-related injuries at three Midwestern hospitals. Joint Commission Journal on Quality \& Patient Safety, 37(2), 81-87. 


\section{Appendix A}

\section{Summary of Primary Research Evidence}

\begin{tabular}{|c|c|c|c|c|c|}
\hline Citation & $\begin{array}{c}\text { Design, } \\
\text { Level } \\
\text { Quality } \\
\text { Grade }\end{array}$ & $\begin{array}{c}\text { Sample } \\
\text { Sample size }\end{array}$ & $\begin{array}{l}\text { Intervention } \\
\text { Comparison } \\
\text { (Definitions } \\
\text { should include } \\
\text { any specific } \\
\text { research tools } \\
\text { used along with } \\
\text { reliability \& } \\
\text { validity) }\end{array}$ & Outcome Definition & $\begin{array}{c}\text { Usefulness } \\
\text { Results } \\
\text { Key Findings }\end{array}$ \\
\hline $\begin{array}{l}\text { Baris, V. K., \& Seren } \\
\text { Intepeler, S. (2019). Views } \\
\text { of key stakeholders on the } \\
\text { causes of patient falls and } \\
\text { prevention interventions: A } \\
\text { qualitative study using the } \\
\text { international classification } \\
\text { of functioning, disability, } \\
\text { and health. Journal of } \\
\text { Clinical Nursing, (3-4), } \\
615 .\end{array}$ & $\begin{array}{l}\text { Research } \\
\text { Design } \\
\text { Descripti } \\
\text { ve } \\
\text { qualitativ } \\
\text { e method } \\
\text { SORT } 3\end{array}$ & $\begin{array}{l}\text { Sample Size: } \\
\text { four MD, four } \\
\text { Charge nurses, } \\
\text { Twelve Nurses, } \\
\text { Four support } \\
\text { staff, Eight } \\
\text { patients, } \\
\text { Eight family } \\
\text { members }\end{array}$ & $\begin{array}{l}\text { Research Tools } \\
\text { Used: } \\
\text { Semi-structured } \\
\text { interview }\end{array}$ & $\begin{array}{l}\text { Discern the perceptions } \\
\text { and recommendations of } \\
\text { the healthcare } \\
\text { professionals, patients, } \\
\text { and family members } \\
\text { regarding falls, } \\
\text { including causative } \\
\text { factors and prevention } \\
\text { practices. }\end{array}$ & $\begin{array}{l}\text { Noted } 71 \text { themes related to triggering situations } \\
\text { for falls, and } 30 \text { of these are related to prevention } \\
\text { interventions. These themes were linked with } 44 \\
\text { categories under five International Classification } \\
\text { of Functioning, Disability and Health domains } \\
\text { and organized accordingly. There is a correlation } \\
\text { between the patient body function to the causes } \\
\text { of falls. There is a correlation between } \\
\text { stakeholders' opinions in successful fall } \\
\text { prevention. Seeking these opinions will improve } \\
\text { the effectiveness of fall prevention programs. It } \\
\text { is recommended for the staff to gather more } \\
\text { comprehensive information from key } \\
\text { stakeholders including all healthcare } \\
\text { professionals, patients, and patient family } \\
\text { members. }\end{array}$ \\
\hline $\begin{array}{l}\text { Dykes, P. C., Carroll, D. L., } \\
\text { Hurley, A., Lipsitz, S., } \\
\text { Benoit, A., Chang, F., } \\
\text { Meltzer, S., Tsurikova, R., } \\
\text { Zuyov, L., \& Middleton, B. } \\
\text { (2010). Fall prevention in } \\
\text { acute care hospitals: a } \\
\text { randomized trial. JAMA, }\end{array}$ & $\begin{array}{l}\text { Randomi } \\
\text { zed Trial } \\
\text { SORT 1 }\end{array}$ & $\begin{array}{l}\text { Cluster } \\
\text { randomized study } \\
\text { conducted } \\
\text { January } 1 \text {, } \\
2009, \text { through } \\
\text { June } 30,2009, \\
\text { comparing } \\
\text { patient fall rates }\end{array}$ & $\begin{array}{l}\text { Data Analysis } \\
\text { Stratified, cluster } \\
\text { randomization } \\
\text { design, with the } \\
\text { randomized } \\
\text { intervention }\end{array}$ & $\begin{array}{l}\text { Investigate if a fall } \\
\text { prevention tool kit } \\
\text { (FPTK) using health } \\
\text { information technology } \\
\text { (HIT) will reduce patient } \\
\text { falls in hospitals. }\end{array}$ & $\begin{array}{l}\text { Patients in the control and intervention units } \\
\text { were comparable, but patients in the control units } \\
\text { were more likely to be the younger population } \\
\text { and of the white race and to have health } \\
\text { insurance. Site adjusted fall rates were } \\
\text { meaningfully higher in control units ( } 4.18) \text { per } \\
1,000 \text { patient-days) than in intervention units } \\
(3.15) \text {. The FPTK was found to be particularly }\end{array}$ \\
\hline
\end{tabular}




\begin{tabular}{|c|c|c|c|c|c|}
\hline $\begin{array}{l}\text { 304(17), 1912-1918. } \\
\text { https://doi.org/10.1001/jam } \\
\underline{\text { a.2010.1567 }}\end{array}$ & & $\begin{array}{l}\text { in four urban US } \\
\text { hospitals in units } \\
\text { that received } \\
\text { usual care (four } \\
\text { units and } 5104 \\
\text { patients) or the } \\
\text { intervention (four } \\
\text { units and } 5160 \\
\text { patients). }\end{array}$ & $\begin{array}{l}\text { at the unit } \\
\text { (cluster) level } \\
\text { within } \\
\text { hospital (strata) } \\
\text { and falls assessed } \\
\text { at the } \\
\text { patient level } \\
\text { Statistical } \\
\text { analyses were } \\
\text { performed } \\
\text { using the SAS } \\
\text { software }\end{array}$ & & $\begin{array}{l}\text { effective with patients aged } 65 \text { years or older } \\
\text { (adjusted rate difference, } 2.08 \text { per } 1,000 \text { patient- } \\
\text { days; Using a fall prevention tool kit in hospital } \\
\text { units compared with usual care significantly } \\
\text { decreased the rate of falls. }\end{array}$ \\
\hline $\begin{array}{l}\text { Hardin, S. R., Dienemann, } \\
\text { J., Rudisill, P., \& Mills, K. } \\
\text { K. (2013). Inpatient fall } \\
\text { prevention: use of in-room } \\
\text { Webcams. Journal of } \\
\text { Patient Safety, 9(1), 29-35. } \\
\text { https://doi.org/10.1097/PTS } \\
. \text { Ob013e3182753e4f }\end{array}$ & $\begin{array}{l}\text { Research } \\
\text { Design } \\
\text { Quantitat } \\
\text { ive study } \\
\text { with a } \\
\text { case- } \\
\text { control, } \\
\text { descripti } \\
\text { ve } \\
\text { design } \\
\text { was } \\
\text { conducte } \\
\text { d at ten } \\
\text { hospitals. } \\
\text { SORT } 2\end{array}$ & $\begin{array}{l}\text { Sample Size: } \\
\text { Adult patients } \\
\text { admitted to the } \\
\text { Medical-Surgical } \\
\text { units from ten } \\
\text { hospitals chosen } \\
\text { from a network } \\
\text { of } 56 \text { hospitals } \\
\mathrm{N}=10\end{array}$ & $\begin{array}{l}\text { Descriptive data } \\
\text { were collected on } \\
\text { every } \\
\text { participating unit. } \\
\text { Data were } \\
\text { collected on } \\
\text { MRA scores, } \\
\text { daily patient } \\
\text { daily, count of } \\
\text { patient eligibility } \\
\text { and consent, } \\
\text { number of falls, } \\
\text { and use of bed } \\
\text { alarms or } \\
\text { Webcams } \\
\text { during the fall } \\
\text { and } \\
\text { characteristics } \\
\text { associated with } \\
\text { each fall for all } \\
\text { study units and } \\
\text { monthly } \\
\text { compliance with } \\
\text { the system fall } \\
\text { protocols. }\end{array}$ & $\begin{array}{l}\text { Compare inpatient falls } \\
\text { on medical surgical } \\
\text { units with and without } \\
\text { Webcams and assessed } \\
\text { the Morse Risk } \\
\text { Assessment (MRA) for } \\
\text { effectiveness in } \\
\text { identifying fall risk. }\end{array}$ & $\begin{array}{l}\text { There were } 185 \text { total falls, } 101 \text { transpired in the } \\
\text { control hospitals and, } 84 \text { occurred in the } \\
\text { intervention hospitals. There were three } \\
\text { injurious falls in the control hospital and one in } \\
\text { the intervention hospital. The use of the MRA } \\
\text { with a 50+ score for high risk is highly } \\
\text { recommended. Recommended more research is } \\
\text { needed on patient acceptance of Webcam as a } \\
\text { form of intervention and usefulness in preventing } \\
\text { falls on several inpatient units or with specific } \\
\text { age groups. The use of valid risk assessments } \\
\text { such as Morse and fall prevention procedures and } \\
\text { guidelines for high-risk patients improve nurse } \\
\text { satisfaction. Webcams are one technology that } \\
\text { may contribute to the observation and will permit } \\
\text { nurses to respond more quickly to prevent falls. }\end{array}$ \\
\hline $\begin{array}{l}\text { Hester, A. L., Tsai, P., } \\
\text { Rettiganti, M. \& Mitchell, } \\
\text { A. (2016). CE. Predicting }\end{array}$ & $\begin{array}{l}\text { Research } \\
\text { Design }\end{array}$ & $\begin{array}{l}\text { Sample Size: } \\
\text { One thousand } \\
\text { three hundred }\end{array}$ & $\begin{array}{l}\text { Research Tools } \\
\text { Used: De- } \\
\text { identified data for }\end{array}$ & $\begin{array}{l}\text { Ascertain which patient } \\
\text { causative factors lead to } \\
\text { injurious inpatient falls. }\end{array}$ & $\begin{array}{l}\text { The analysis noted a statistically significant } \\
\text { correlation of injurious falls with having a } \\
\text { primary diagnosis. The study revealed that }\end{array}$ \\
\hline
\end{tabular}




\begin{tabular}{|c|c|c|c|c|c|}
\hline $\begin{array}{l}\text { injurious falls in the } \\
\text { hospital setting: } \\
\text { implications for practice, } \\
\text { American Journal of } \\
\text { Nursing, } 116(9), 24-31 . \\
\text { http://doi.org/10.1097/01.N } \\
\text { AJ.0000494688.10004.85 } \\
\end{array}$ & $\begin{array}{l}\text { Quantitat } \\
\text { ive } \\
\text { retrospec } \\
\text { tive chart } \\
\text { review } \\
\text { SORT 1 }\end{array}$ & $\begin{array}{l}\text { sixty-nine } \\
\text { patients who fell } \\
\text { between Jan } \\
2006-O c t ~ 013 . \\
\text { Patients } 18 \text { years } \\
\text { and older }\end{array}$ & $\begin{array}{l}\text { electronic } \\
\text { medical records } \\
\text { (EMR) Data } \\
\text { Analysis: } \\
\text { Bivariate analysis } \\
\text { was used and } \\
\text { SPSS }\end{array}$ & & $\begin{array}{l}40.6 \% \text { of patients with ill-defined diagnoses } \\
\text { sustained injurious falls. To prevent injurious } \\
\text { falls, clinicians should consider the patients' } \\
\text { diagnoses in the care management. }\end{array}$ \\
\hline $\begin{array}{l}\text { Sand-Jecklin, K., Johnson, } \\
\text { J., Tringhese, A., Daniels, } \\
\text { C., \& White, F. (2019). } \\
\text { Video monitoring for fall } \\
\text { prevention and patient } \\
\text { safety: process evaluation } \\
\text { and improvement. Journal } \\
\text { of Nursing Care Quality, } \\
\text { 34(2), } 145 \text {. }\end{array}$ & $\begin{array}{l}\text { Research } \\
\text { Design } \\
\text { Quasi- } \\
\text { experime } \\
\text { ntal } \\
\text { SORT } 3\end{array}$ & $\begin{array}{l}\text { Sample: } \\
\text { Adult patients } \\
\text { admitted to a } \\
\text { neuroscience } \\
\text { unit, medical } \\
\text { unit, or one of } \\
\text { two medical- } \\
\text { surgical units } \\
\text { within one } \\
\text { hospital. N= } \\
\text { Four units } \\
\text { Setting: Hospital } \\
\text { in the Mid- } \\
\text { Atlantic Region }\end{array}$ & $\begin{array}{l}\text { Interview with } \\
\text { staff and patients, } \\
\text { including video } \\
\text { monitors. } \\
\text { Patients and } \\
\text { family members } \\
\text { of monitored } \\
\text { patients } \\
\text { completed } 52 \\
\text { surveys. These } \\
\text { patients and } \\
\text { family are } \\
\text { representative of } \\
\text { all the monitor- } \\
\text { available units. }\end{array}$ & $\begin{array}{l}\text { Appraise the } \\
\text { surveillance process at a } \\
\text { large teaching hospital } \\
\text { to create improvements } \\
\text { and standardize } \\
\text { monitoring practices. } \\
\text { Aims of the study were } \\
\text { to identify (1) the } \\
\text { nursing staff and } \\
\text { monitor technicians' } \\
\text { perspectives on the } \\
\text { video monitoring (VM) } \\
\text { process, including areas } \\
\text { for improvement of the } \\
\text { process; (2) } \\
\text { patient/family } \\
\text { perceptions related to } \\
\text { patient monitoring, such } \\
\text { as the perceptions of } \\
\text { communication related } \\
\text { to the process, its impact } \\
\text { on patient safety, and } \\
\text { guarding of privacy; and } \\
\text { (3) to revise and } \\
\text { standardize the } \\
\text { procedure for VM and } \\
\text { enhance its value for } \\
\text { protecting patient safety. }\end{array}$ & $\begin{array}{l}\text { Pre-implementation had } 3.9 \text { falls per } 1,000 \\
\text { patient days, and post-implementation had } 28 \\
\text { falls per } 1,000 \text { patient days. The decrease in the } \\
\text { rate was statistically significant. There were six } \\
\text { injurious falls on non-monitored patients, and no } \\
\text { injurious dals on non-monitored patients, } \\
\text { statistical significance could not be determined. }\end{array}$ \\
\hline $\begin{array}{l}\text { Porter, R. B., Cullen, L., } \\
\text { Farrington, M., Matthews, } \\
\text { G., \& Tucker, S. (2018). } \\
\text { CE: Original research: } \\
\text { Exploring clinicians' }\end{array}$ & $\begin{array}{l}\text { Research } \\
\text { Design: } \\
\text { Qualitati } \\
\text { ve design } \\
\text { focus }\end{array}$ & $\begin{array}{l}\text { Sample Size: } \\
20 \text { clinicians }(18 \\
\text { F \&2 M) ( } 5 \\
\text { Nurses \& } 5 \text { Non - } \\
\text { Nurse) }\end{array}$ & $\begin{array}{l}\text { Research Tools } \\
\text { Used: } \\
\text { Semi-structured } \\
\text { interview guide }\end{array}$ & $\begin{array}{l}\text { Examine the views of } \\
\text { the inter-professional } \\
\text { health care team to } \\
\text { determine the } \\
\text { knowledge gap between }\end{array}$ & $\begin{array}{l}\text { There were two themes related to falls identified, } \\
\text { namely: The patterns of communication within } \\
\text { the health care team and the hospital } \\
\text { organizational practices influences. There is an } \\
\text { association between these two themes in the }\end{array}$ \\
\hline
\end{tabular}




\begin{tabular}{|c|c|c|c|c|c|}
\hline $\begin{array}{l}\text { perceptions about } \\
\text { sustaining an evidence- } \\
\text { based fall prevention } \\
\text { program. American Journal } \\
\text { of Nursing, (5), } 24 \text {. } \\
\text { http://doi.org/10.1097/01.N } \\
\text { AJ.0000532806.35972.29 }\end{array}$ & $\begin{array}{l}\text { groups } \\
\text { and } \\
\text { interview } \\
\text { s } \\
\text { SORT } 3\end{array}$ & & $\begin{array}{l}\text { to direct } \\
\text { conversation. } \\
\text { Data Analysis: } \\
\text { Inductive } \\
\text { approach } \\
\text { pragmatic form }\end{array}$ & $\begin{array}{l}\text { implementation and } \\
\text { sustenance of } \\
\text { evidenced-based } \\
\text { practice fall prevention } \\
\text { interventions for } \\
\text { hospitalized patients. }\end{array}$ & $\begin{array}{l}\text { sustainability of the EBP fall prevention } \\
\text { program. Having an inter-professional } \\
\text { collaborative approach has been deemed } \\
\text { essential to the appropriate communication and } \\
\text { development of timely actions related to fall } \\
\text { Organizations need to develop standardized } \\
\text { protocols to support inter-professional team } \\
\text { collaboration and the coordinated planning } \\
\text { around the sustained use of an evidence-based } \\
\text { fall prevention program. }\end{array}$ \\
\hline $\begin{array}{l}\text { Radecki, B., Reynolds, S., } \\
\text { \& Kara, A. (2018). Original } \\
\text { article: Inpatient fall } \\
\text { prevention from the } \\
\text { patient's perspective: A } \\
\text { qualitative study. Applied } \\
\text { Nursing Research, 43, 114- } \\
119 . \\
\text { http://doi.org/10.1016/j.apn } \\
\underline{\text { r.2018.08.001 }}\end{array}$ & $\begin{array}{l}\text { Research } \\
\text { Design: } \\
\text { Descripti } \\
\text { ve } \\
\text { qualitativ } \\
\text { e- } \\
\text { perceptiv } \\
\text { e } \\
\text { interview } \\
\text { SORT } 2\end{array}$ & $\begin{array}{l}\text { Sample Size: } \\
12 \text { hospitalized } \\
\text { patients }(7 \mathrm{M}, \\
5 \mathrm{~F}) \\
\text { Mean age } 65.2\end{array}$ & $\begin{array}{l}\text { Research Tools } \\
\text { Used: } \\
\text { Interview guide. } \\
\text { Data Analysis: } \\
\text { Thematic } \\
\text { analysis of } \\
\text { patients' } \\
\text { responses }\end{array}$ & $\begin{array}{l}\text { Examine the patient's } \\
\text { views of fall prevention } \\
\text { in an acute care setting. } \\
\text { This process will assist } \\
\text { in the development and } \\
\text { design of patient- } \\
\text { centered fall prevention } \\
\text { strategies. }\end{array}$ & $\begin{array}{l}\text { Qualitative analysis revealed three significant } \\
\text { themes, namely: description of patient's beliefs } \\
\text { of their fall risks, intervention such as bed } \\
\text { alarms, and usefulness of interventions and the } \\
\text { barriers to practice in fall prevention. Patients } \\
\text { were aware but believed that their ability to } \\
\text { mobilize is a crucial factor. Organization leaders } \\
\text { need to develop a shared objective that will allow } \\
\text { the intervention to meet the patient's needs and } \\
\text { nurses' judgment. The organizations need to } \\
\text { deter from clinician-led to patient-centered fall } \\
\text { prevention. }\end{array}$ \\
\hline $\begin{array}{l}\text { Schwenk, M., Lauenroth, } \\
\text { A., Stock, C., Moreno, R. } \\
\text { R., Oster, P., McHugh, G., } \\
\text { Todd, C., \& Hauer, K. } \\
\text { (2012). Definitions and } \\
\text { methods of measuring and } \\
\text { reporting on injurious falls } \\
\text { in randomized controlled } \\
\text { fall prevention trials: a } \\
\text { systematic review. BMC } \\
\text { Medical Research } \\
\text { Methodology, 12, 50. } \\
\underline{\text { https://doi.org/10.1186/147 }} \\
\underline{\text { 1-2288-12-50 }}\end{array}$ & $\begin{array}{l}\text { Research } \\
\text { Design } \\
\text { Randomi } \\
\text { zed } \\
\text { Control } \\
\text { Trial } \\
\text { SORT } 2\end{array}$ & $\begin{array}{l}\text { Sample } \\
\text { Forty-one } \\
\text { articles were } \\
\text { included. The } \\
\text { systematic } \\
\text { analysis of the } \\
\text { methodology } \\
\text { applied in RCTs } \\
\text { revealed } \\
\text { considerable } \\
\text { variations in the } \\
\text { definition and } \\
\text { approaches } \\
\text { employed to } \\
\text { measure and } \\
\text { document } \\
\text { injurious falls. }\end{array}$ & $\begin{array}{l}\text { Data extraction } \\
\text { was performed by } \\
\text { three independent } \\
\text { reviewers using a } \\
\text { standardized } \\
\text { form. } \\
\text { A descriptive } \\
\text { statistical } \\
\text { analysis was } \\
\text { performed. }\end{array}$ & $\begin{array}{l}\text { Thoroughly review the } \\
\text { range of case definitions } \\
\text { and methods used to } \\
\text { measure and report on } \\
\text { injurious falls in } \\
\text { randomized controlled } \\
\text { trials (RCTs) on fall } \\
\text { prevention. }\end{array}$ & $\begin{array}{l}\text { Customizing the fall prevention education by } \\
\text { addressing validity and motivation positively } \\
\text { improved fall threats information. Merging } \\
\text { motivational tactics with multimedia } \\
\text { education improved the effectiveness of the } \\
\text { intervention in encouraging fall prevention } \\
\text { behaviors. The authors also recommend using a } \\
\text { standardized methodology in future randomized } \\
\text { controlled trials, including a comprehensive } \\
\text { system for categorizing and defining injurious } \\
\text { falls and standardized methods of gathering and } \\
\text { reporting detrimental falls data. }\end{array}$ \\
\hline
\end{tabular}




\begin{tabular}{|c|c|c|c|c|c|}
\hline $\begin{array}{l}\text { Votruba, L., Graham, B., } \\
\text { Wisinski, J., \& Syed, A. } \\
\text { (2016). Video monitoring } \\
\text { to reduce falls and patient } \\
\text { companion costs for adult } \\
\text { inpatients. Nursing } \\
\text { Economic\$, 34(4), 185- } \\
\text { 189. }\end{array}$ & $\begin{array}{l}\text { Research } \\
\text { Design } \\
\text { Prospecti } \\
\text { ve } \\
\text { Descripti } \\
\text { ve Study } \\
\text { SORT } 3\end{array}$ & $\begin{array}{l}\text { Sample Adult } \\
\text { patients admitted } \\
\text { to the critical care } \\
\text { unit, } \\
\text { neuroscience } \\
\text { unit, or senior } \\
\text { adult unit within } \\
\text { one hospital. N= } \\
\text { Three units } \\
\text { Setting: Magnet- } \\
\text { designated } \\
\text { hospital. A total } \\
\text { of } 828 \text { unique } \\
\text { adult patients } \\
\text { were observed } \\
\text { during } 992 \text { video } \\
\text { monitoring } \\
\text { episodes. }\end{array}$ & $\begin{array}{l}\text { Data analysis. } \\
\text { Most data were } \\
\text { analyzed using } \\
\text { simple } \\
\text { descriptive } \\
\text { statistics, except } \\
\text { the change in } \\
\text { falls, was also } \\
\text { analyzed with } \\
\text { paired t-test } \\
\text { using a 95\% } \\
\text { confidence } \\
\text { interval. }\end{array}$ & $\begin{array}{l}\text { Assess the effectiveness } \\
\text { of remote video } \\
\text { monitoring with a } \\
\text { dedicated telesitter to } \\
\text { reduce falls and decrease } \\
\text { patient sitter usage in the } \\
\text { inpatient adult } \\
\text { population. }\end{array}$ & $\begin{array}{l}\text { Pre-implementation had } 17 \% \text { falls per patient } \\
\text { discharge and post-implementation had } 1.1 \% \\
\text { falls per patient discharge }(\mathrm{p}<0.0001,95 \% \mathrm{CI}) \text {. } \\
\text { The result was a significant reduction in the rate } \\
\text { of falls, but due to the research design, statistical } \\
\text { significance could not be determined. There is } \\
\text { an estimated annual savings of somewhere } \\
\text { between } \$ 77,200 \text { to } \$ 120,000 \text {. The cost of } \\
\text { staffing for the video was } \$ 120,000 \text {. }\end{array}$ \\
\hline $\begin{array}{l}\text { Wong, C., A., } \\
\text { Recktenwald, A., J., Jones, } \\
\text { M., L., Waterman, B., M., } \\
\text { Bollini, M., L., \& Dunagan, } \\
\text { W., Claiborne. (2011). The } \\
\text { cost of serious fall-related } \\
\text { injuries at three Midwestern } \\
\text { hospitals. Joint Commission } \\
\text { Journal on Quality \& } \\
\text { Patient Safety, 37(2), 81- } \\
\text { 87. }\end{array}$ & $\begin{array}{l}\text { Research } \\
\text { Design } \\
\text { Retrospe } \\
\text { ctive } \\
\text { Case- } \\
\text { Control } \\
\text { Study } \\
\text { SORT } 1\end{array}$ & $\begin{array}{l}\text { Sample } \\
\text { Cases were } \\
\text { randomly } \\
\text { coordinated to } \\
\text { two controls by } \\
\text { hospital, age } \\
\text { within five years, } \\
\text { year of discharge, } \\
\text { and diagnosis- } \\
\text { related group } \\
\text { (DRG). Three } \\
\text { hospitals were } \\
\text { used to identify } \\
\text { cases. }\end{array}$ & $\begin{array}{l}\text { Data Analysis } \\
\text { A parametric } \\
\text { testing was used } \\
\text { to determine } \\
\text { distribution of } \\
\text { costs and LOS. } \\
\text { Two methods of } \\
\text { analysis were } \\
\text { used, regression } \\
\text { (univariate and } \\
\text { multivariate) and } \\
\text { OBM to evaluate } \\
\text { cost and LOS to } \\
\text { be attributed to } \\
\text { the serious fall. } \\
\text { Analysis by } \\
\text { SPSS and SAS. }\end{array}$ & $\begin{array}{l}\text { 1) Estimate the current } \\
\text { cost and length of stay } \\
\text { (LOS) that can be } \\
\text { attributed to a fall with } \\
\text { serious injury. } \\
\text { 2) Evaluate the use of } \\
\text { optimal bipartite } \\
\text { matching (OBM) } \\
\text { analysis }\end{array}$ & $\begin{array}{l}\text { Multivariate analysis showed } \$ 13,316 \text { more costs } \\
\text { due to serious injury fall }(\mathrm{p}<.01 ; 95 \% \mathrm{CI} \text {, } \\
\$ 1,395-\$ 35,561) \text { and that these fallers stayed } 6.3 \\
\text { days lengthier than non-fallers ( } \mathrm{p}<.001 ; 95 \% \mathrm{CI} \text {, } \\
2.4-14.9) \text {. Univariate analysis showed that fallers } \\
\text { with serious injury were more likely to have } \\
\text { diabetes with organ damage, moderate to severe } \\
\text { renal disease, and a higher mean score on the } \\
\text { Charlson Comorbidity Index. OBM analysis } \\
\text { indicated Serious injury fallers cost an extra } \\
\$ 13,806 \text { more ( }<.001 ; 95 \% \mathrm{CI}, \$ 5,808- \\
\$ 29,450) \text { and stayed } 6.9 \text { days longer }(\mathrm{p}<.001 ; \\
95 \% \text { CI, } 2.8-14.9) \text {. Patients who fell and } \\
\text { sustained a serious injury had higher expenses } \\
\text { and longer LOS in these three hospitals. }\end{array}$ \\
\hline
\end{tabular}

Legend: (EBP’ Evidence-based Practice; EMR, Electronic Medical Record; MRS, Morse Risk Assessment, OBM, Optimal bipartite matching; SORT, Strength of Recommendation Taxonomy; SD, Standard Deviation; SPSS, Statistical Package for Social Sciences, VM, Video monitoring) 
Patient Educational Handouts

\section{TELESITTER: PATIENT MONITORING TECHNOLOGY}

Protecting patients from falls

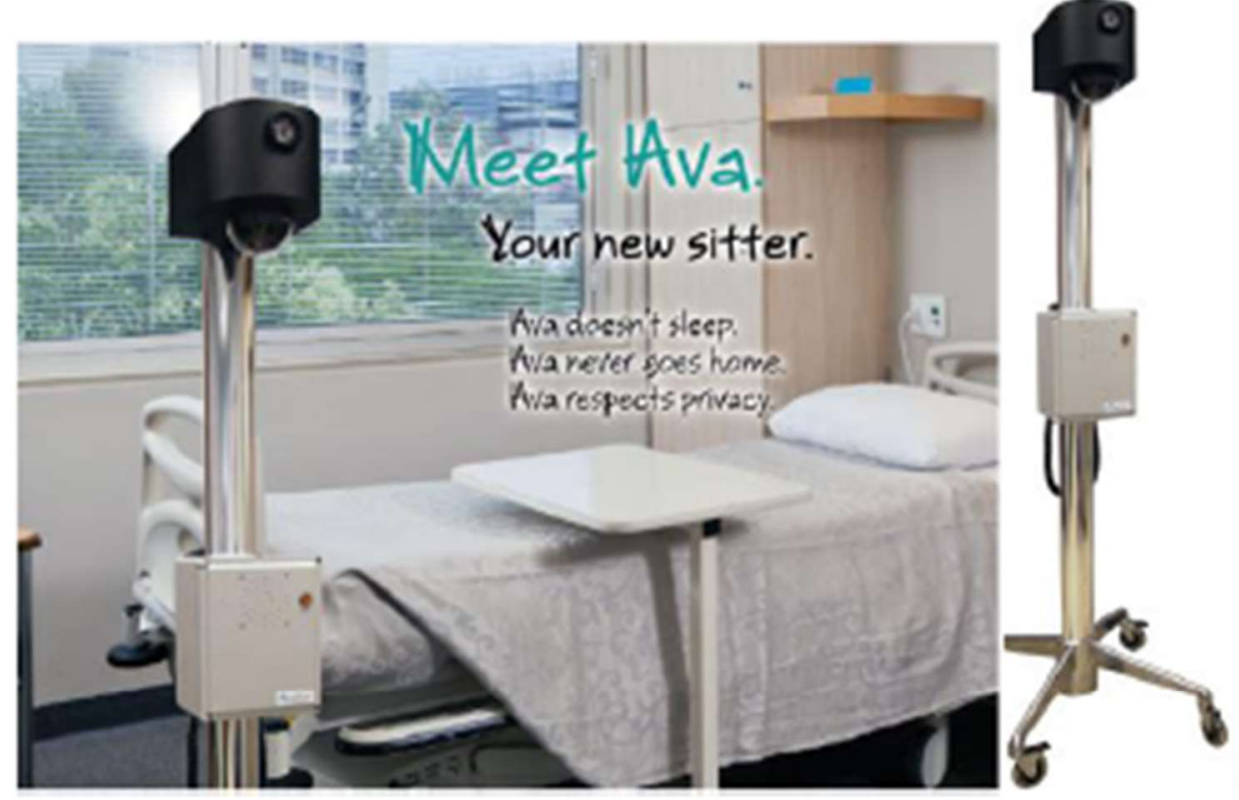

Patient safery and privacy are our highest prionities. For this reason, we are using TeleSitter, a patient mocitoring device that helps decrease your risk of bills. Falls may cause injunes ranging from scrapes and bruises, to broken bones or serious head injunies. This can lead to a longer hospital stay.

\section{HOW TELESITTER WORKS}

The TeleSitter monitoring device is a tool that we use to ensure that you are safe, even if you are alone in your room It has a video camera and two-way adio, which allows a trained staff member to see and spenk to you. When you are trying to get up, the staff member will ask you to stay in bed until a healthcare provider amives in the rocm to provide help. Staff members will monitor you from a central rocom by watching a video feed They can see you all of the time-except when TeleSitter is set to "privacy mode." However, the only time they can bear you is when they talls to you over the spenker. TeleSitter does not ever record video or audio. A member of the mursing staff is always available whenever you need anything. Use your rurse call button to ask for help. When the TeleSitter light is on, the staff member who is monitoring you can see you. When the light is off the pnivacy cover is on, and they cannot see you. The privacy cover is used when your doctor or urse is providing care, and when you are dressing. bathing, or using the toilet. When the doctor or mrse is firished they will ask the staff member to remove the privacy cover and resume mocitoring

Your nurse decides if you no longer need the monitoring device. When your health has improved, and you are safe from falls or injury. TeleSitter mocitocing can be stopped.

Questions about TeleSitter? Ask your nurse for more information. 


\section{TELESITTER: TECNOLOGÍA PARA EL MONITOREO DE PACIENTES}

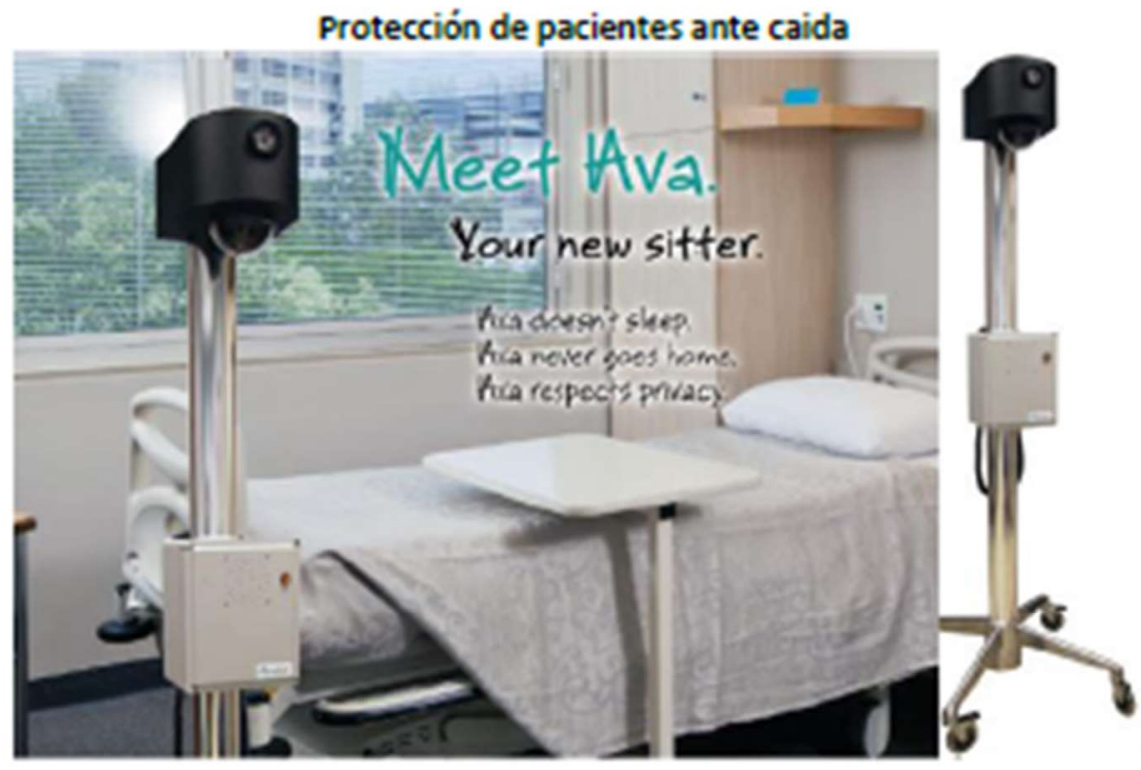

La seguridad y privacidad del paciente son nuestras prioridades. Por esta razín, unlimmos el dispositivo de mocitcreo de pacientes TeleSitter que ayuda a dismimir su niesgo de caídas. Las caídas pueden crasar lesioces que van desde raspones y moretones a fracturas de huesos o lesiones graves en la caben. Esto puede generar una estadia prolocigada en el hospital.

\section{COMO FUNCIONA EL TELESITTER}

El dispositivo de monitoreo TeleSitter es una berramienta que unliznmos para garantizar su seguridad incluso si usted está solo en su babitación. Tiene una címara de video y audio bidireccional que permite a un miembro capacitado del personal verlo y hablar con usted. Cundo intente levartarse, el miembro del personal le pedirá que perminezca en su cama hasta que legue un medico a la habitación para ayudarle.

Los miembros del personal le moritorearín desde una hatitación central al observar la transmisión por vídeo. Pueden verlo todo el tiempo, except cuando el TeleSitter está ajustado en "modo de privacidac". Sin embargo, solo pueden escucharle cuando le hablan a traves del altavoz. El TeleSitter nunca gaba vídeo ni audio. Siempre hobrá un miembro del personal disponible cuando usted necesite algo. Utilice el botcón de lamada a la enfemsera para pedir ayuda.

Cundo la hz del TeleSitter está encendida, el miembro del perscosl que esta supervisando puede verlo. Cuando la hzz está apagads, la cubierta de privacidad esta activada y no puede verlo. La cubierta de privacidad se utiliza cuando el médico o la enfermera lo estín atendiendo, y cuando usted se viste, se baín 0 esta usando el inodoro. Cuando el médico o la enfermera termingn, le pedirán al miembro del personsl eliminor la cubierta de privacidad y reanudar el monitoreo. Su enfermera es quien decide gi ya no necesita el dispositivo de mocitoreo. Cunndo su salud ha mejorado y está a salvo de coerse o lesionurse, puede detenerse el monitoreo con el TeleSitter.

¿Tiene preguntas sobre el TeleSitter? Solicite más información a su enfermera 


\section{Appendix C}

Morse Fall Scale Assessment Tool

\begin{tabular}{|c|c|c|}
\hline Variable & Numeric Value & \\
\hline \multirow[t]{2}{*}{ 1. History of falling } & No & 0 \\
\hline & Yes & 25 \\
\hline \multirow[t]{2}{*}{ 2. Secondary diagnosis } & No & 0 \\
\hline & Yes & 15 \\
\hline \multicolumn{3}{|l|}{ 3. Ambulatory aid } \\
\hline Non/bed rest/nurse assist & & 0 \\
\hline Crutches/cane/walker & & 15 \\
\hline Furniture & & 30 \\
\hline \multirow[t]{2}{*}{ 4. IV or IV access } & No & 0 \\
\hline & Yes & 20 \\
\hline \multicolumn{3}{|l|}{ 5. Gait } \\
\hline Normal/bed rest/wheelchair & & 0 \\
\hline Weak & & 10 \\
\hline Impaired & & 20 \\
\hline \multicolumn{3}{|l|}{ 6. Mental status } \\
\hline Orientated to own ability & & 0 \\
\hline Overestimates or forgets limitations & & 15 \\
\hline Morse Falls Scale Score & Total & \\
\hline \multicolumn{3}{|l|}{ Interpretation } \\
\hline \multicolumn{3}{|l|}{ No risk $<25$} \\
\hline \multicolumn{3}{|l|}{ Moderate risk $26-45$} \\
\hline High risk >46 & & \\
\hline
\end{tabular}


Appendix D

Educational Flyers

\section{TELESITTER \\ CLINICAL CHAMPION \\ CLASS}

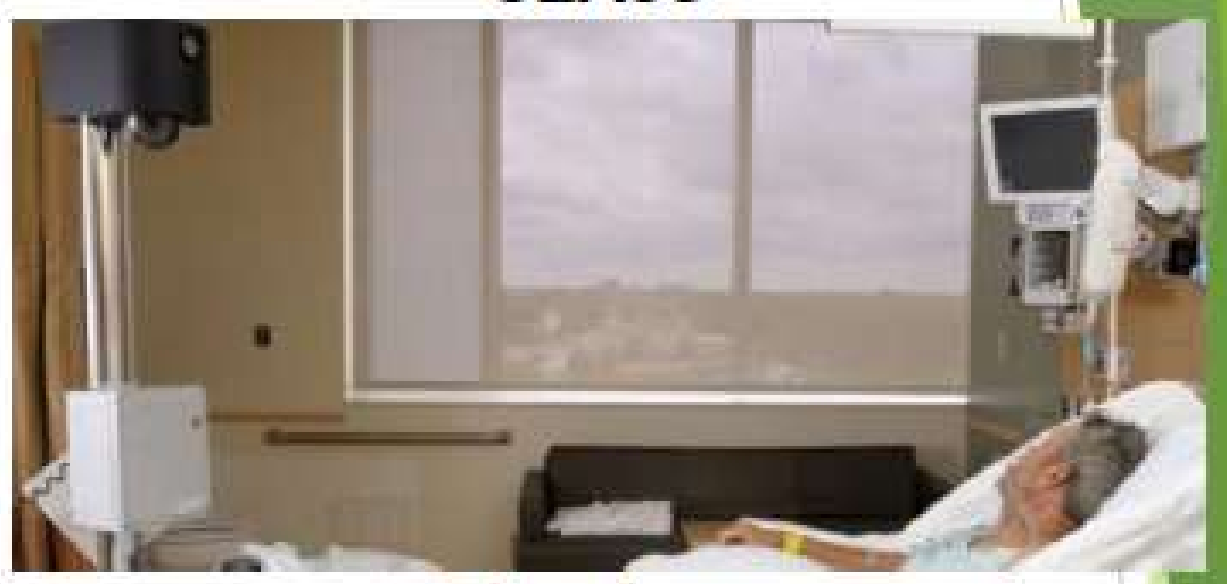

Date

To be determined

Times:

0730-0815

$\&$

$1530-1615$

Target Audience: MANAGEMENT \& CHARGE RNs - Max 8 per Unit

For questions, please contact: 


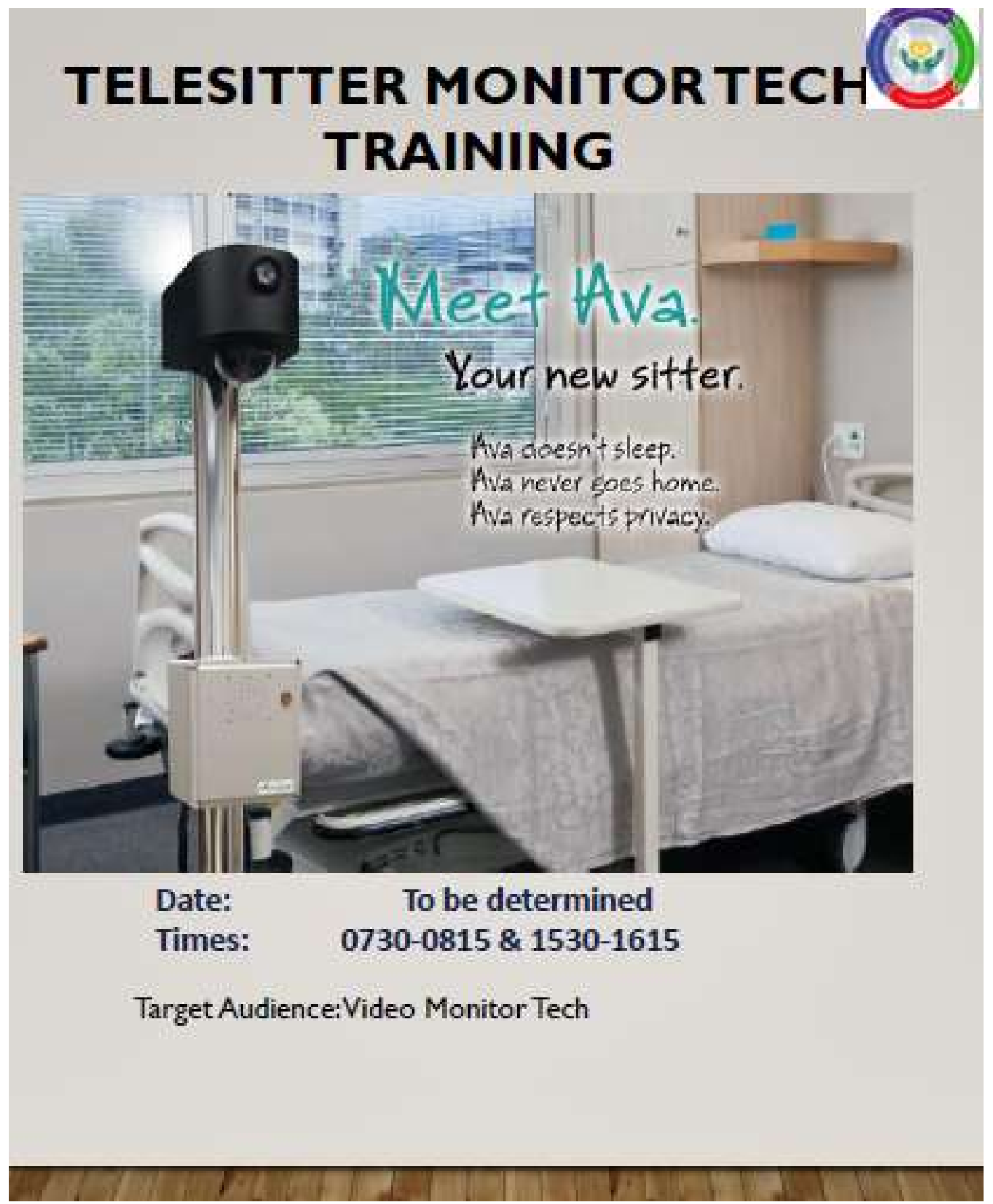




\section{Appendix E}

\section{Training Rosters}

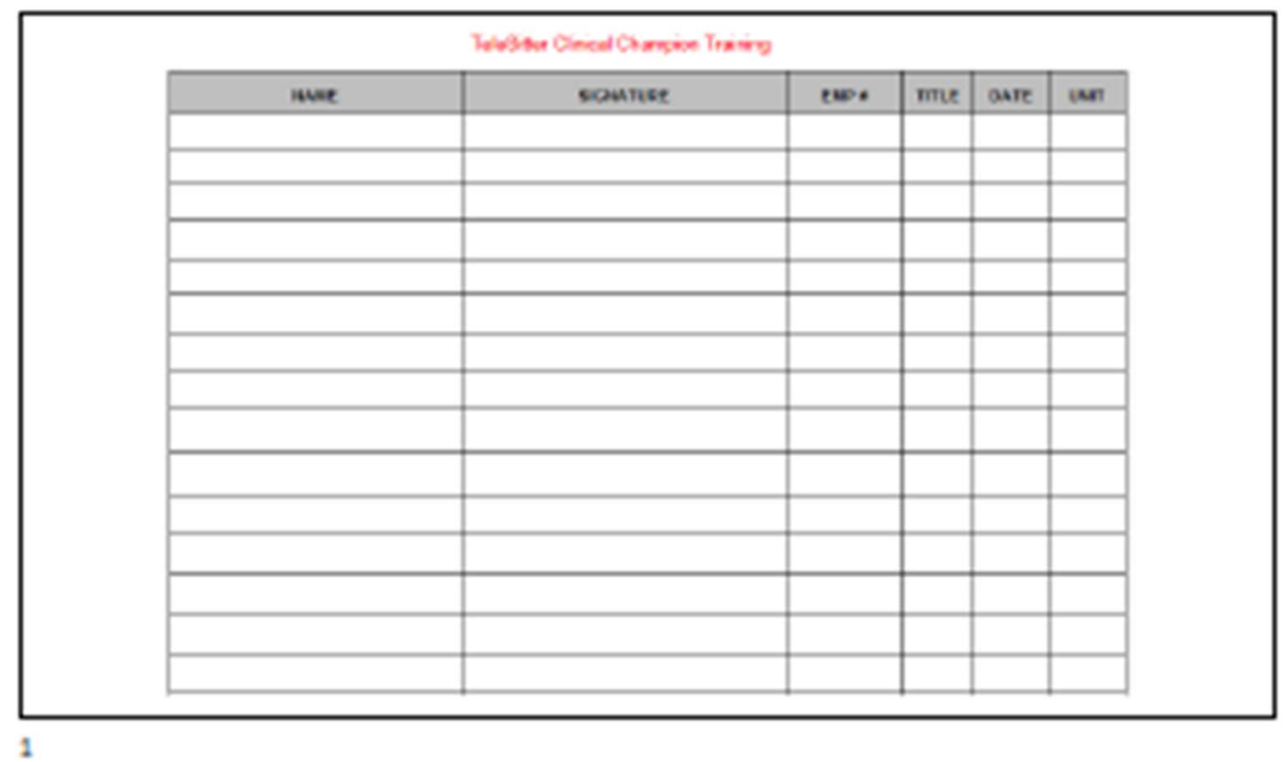

1

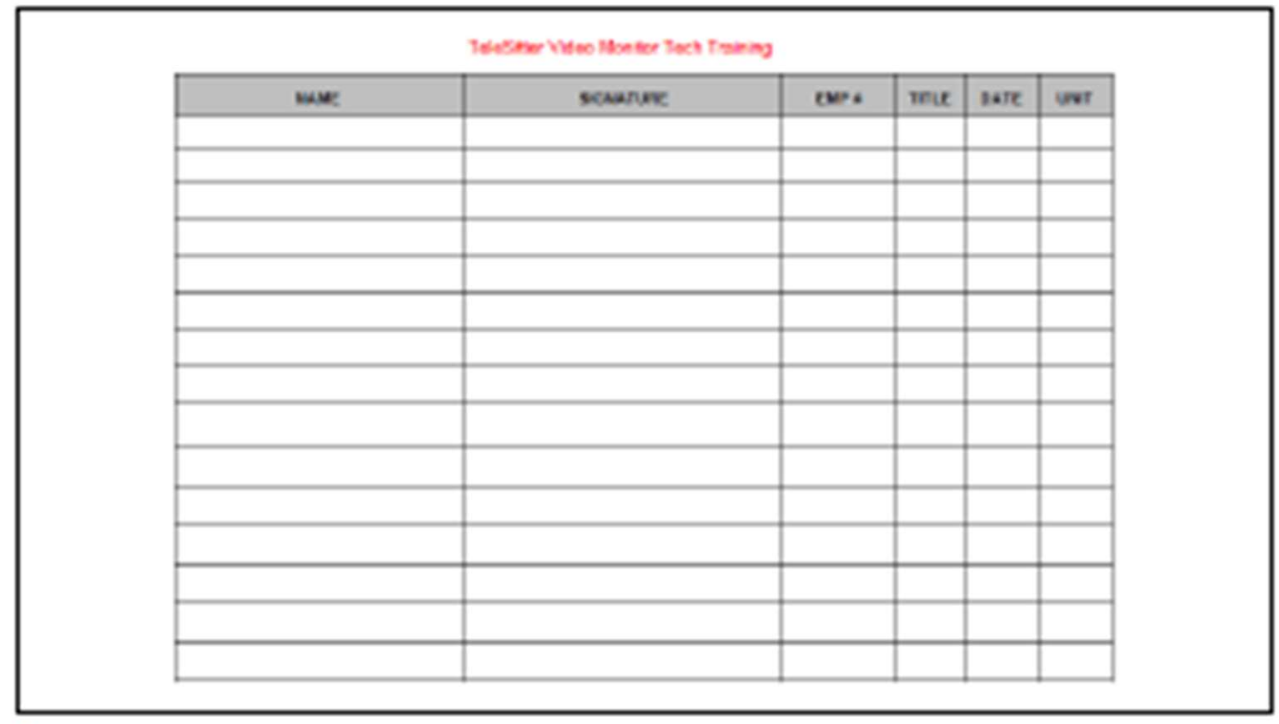

2 


\section{Appendix F}

\section{Clinical Champion Video Monitoring Training}

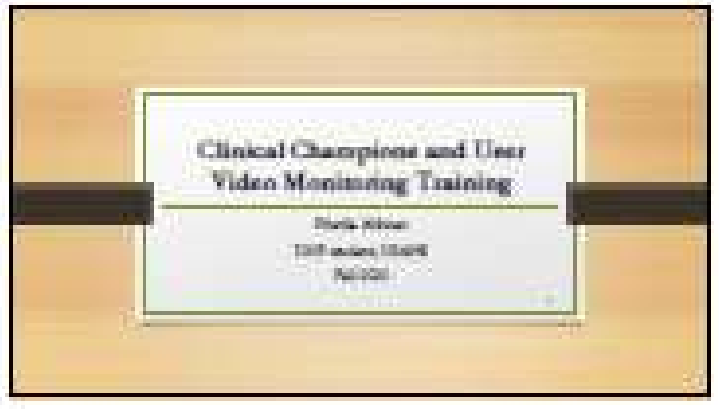

1

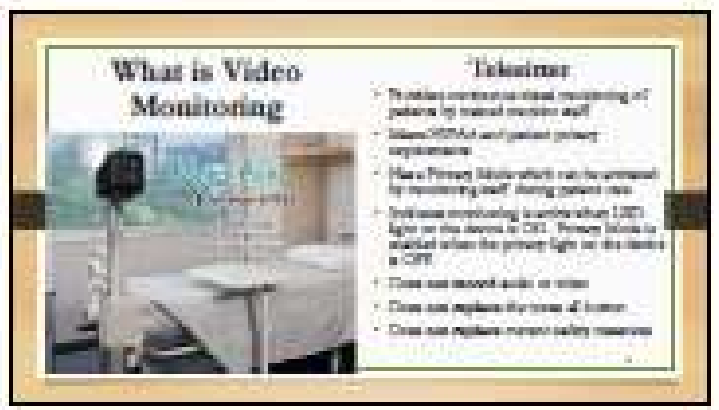

3

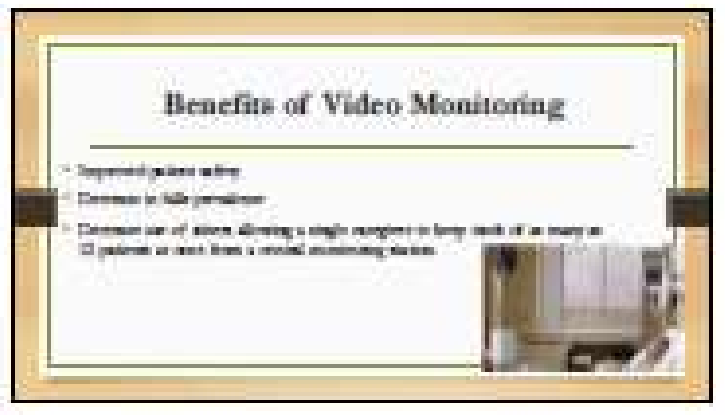

5

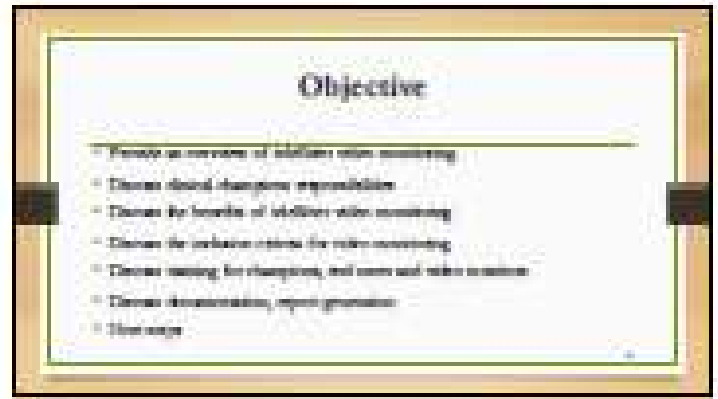

2

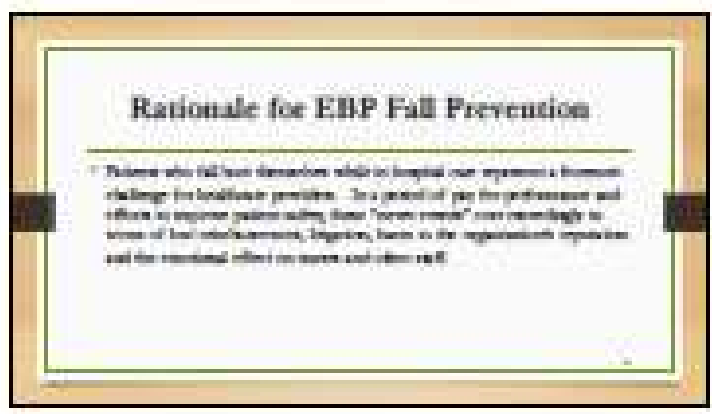

4

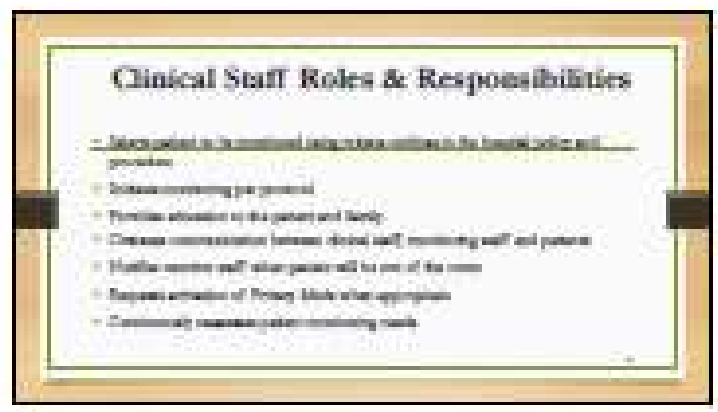

6 


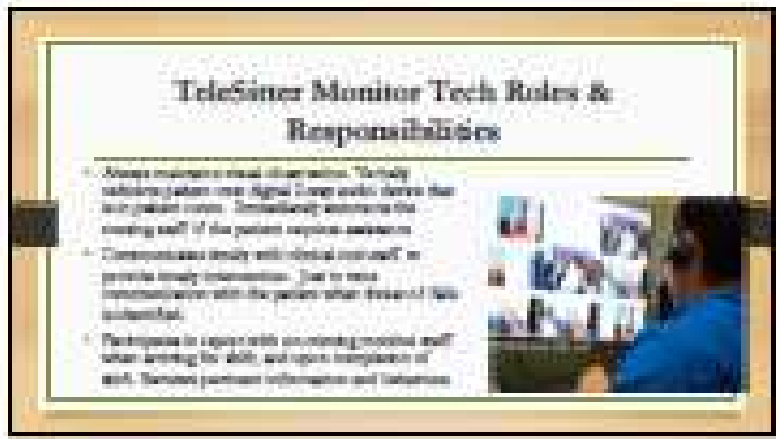

7

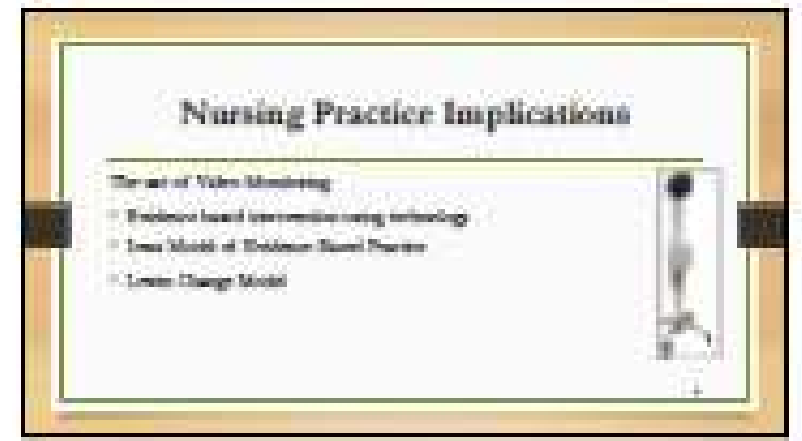

$\mathbb{B}$

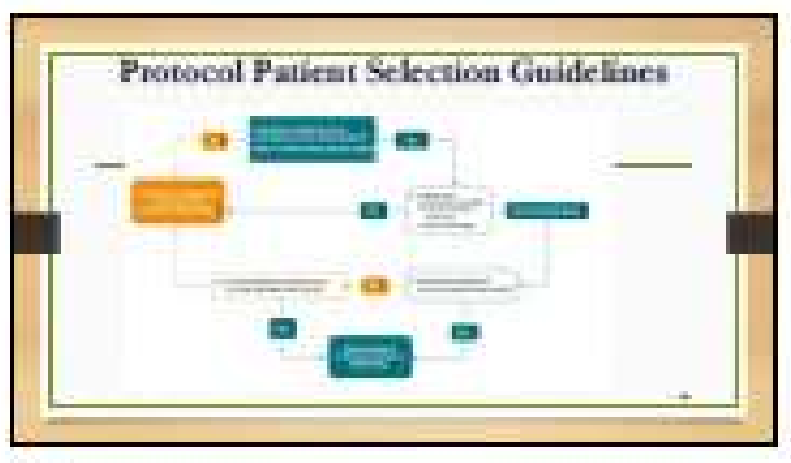

10

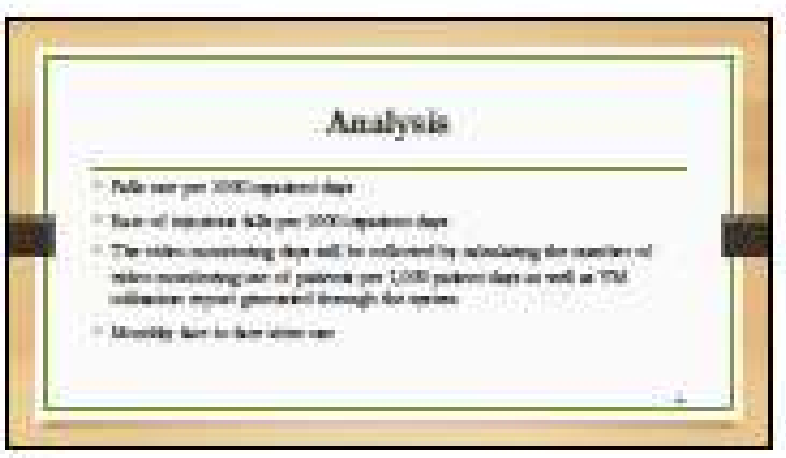

17 

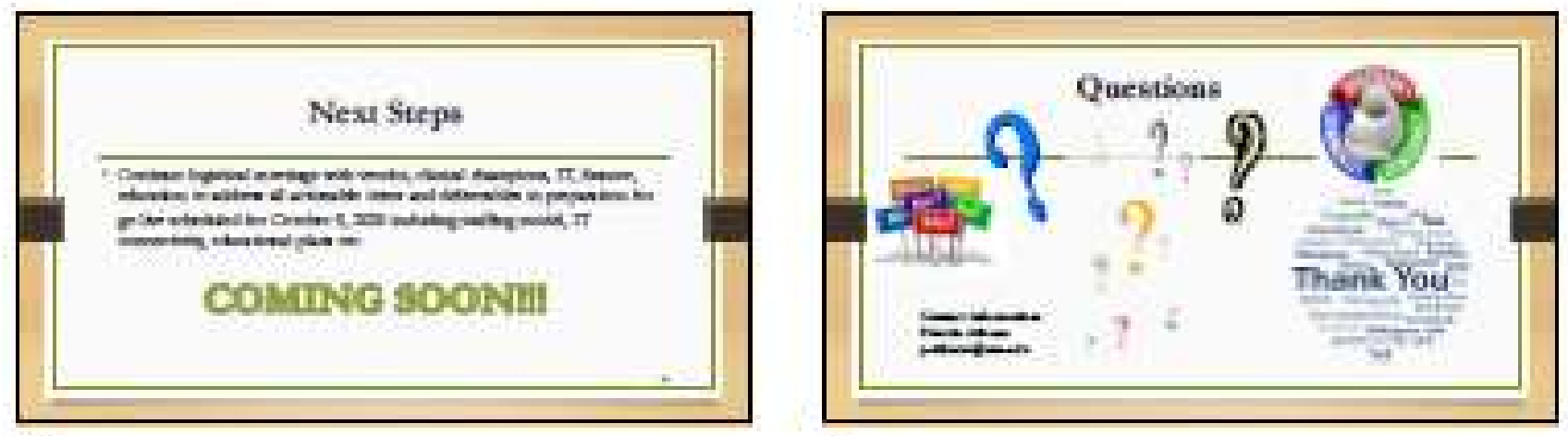

13 


\section{Appendix G}

TeleSitter Video Monitoring Training

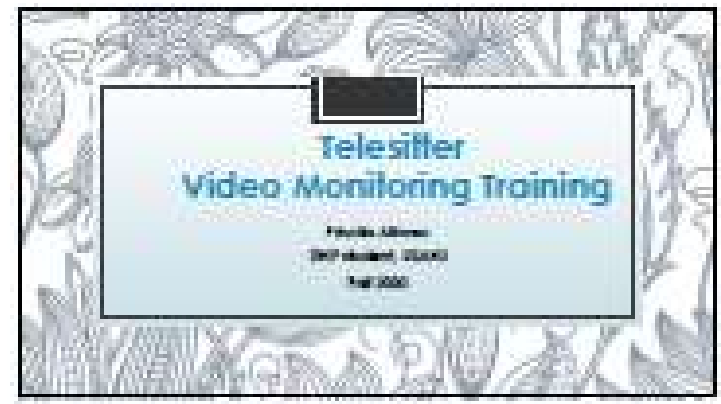

1

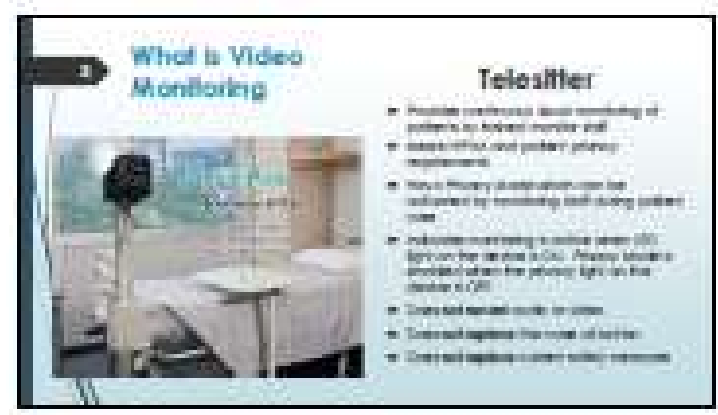

3

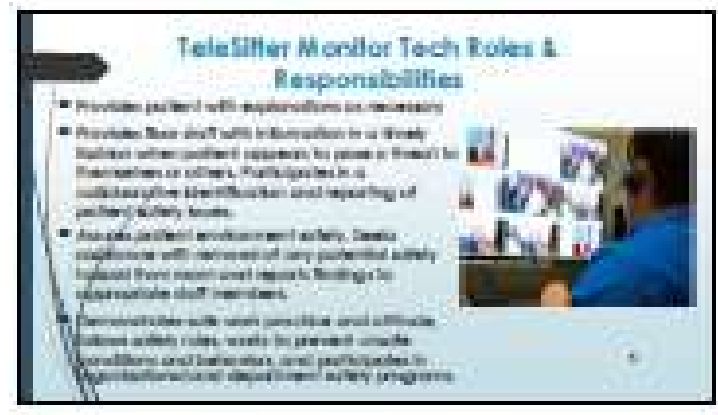

5
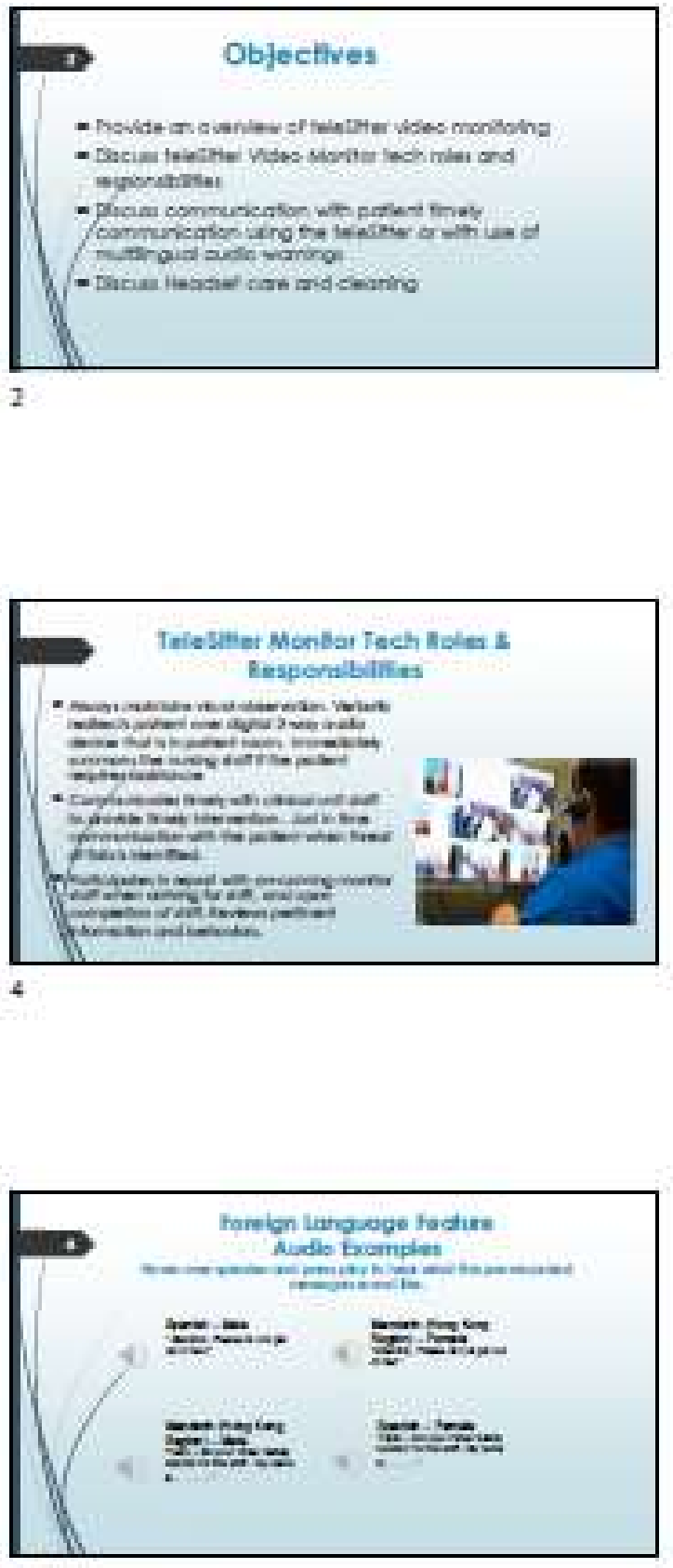

6 

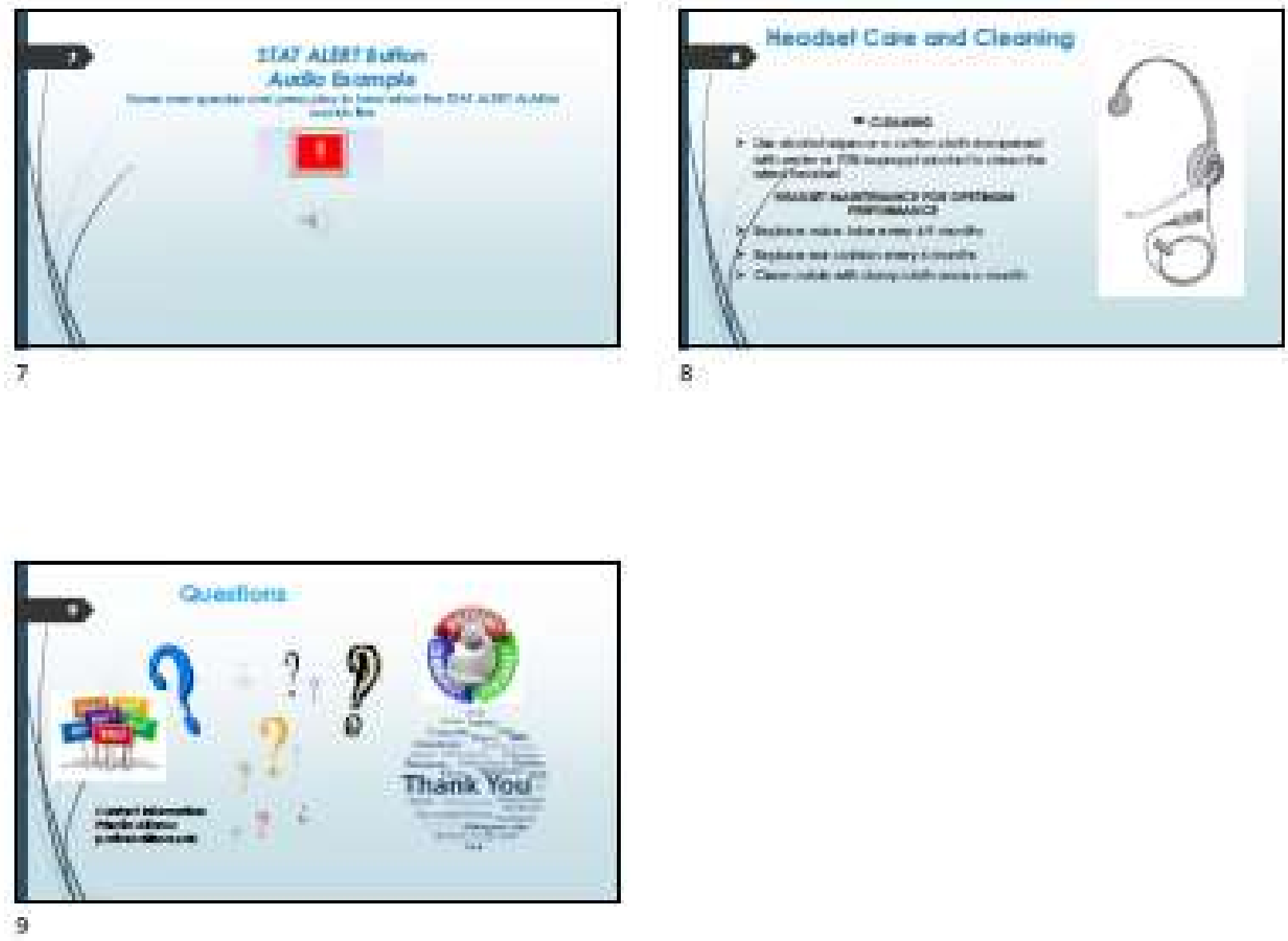


\section{Appendix H}

\section{VIDEO MONITORING PATIENT SELECTION CRITERIA}

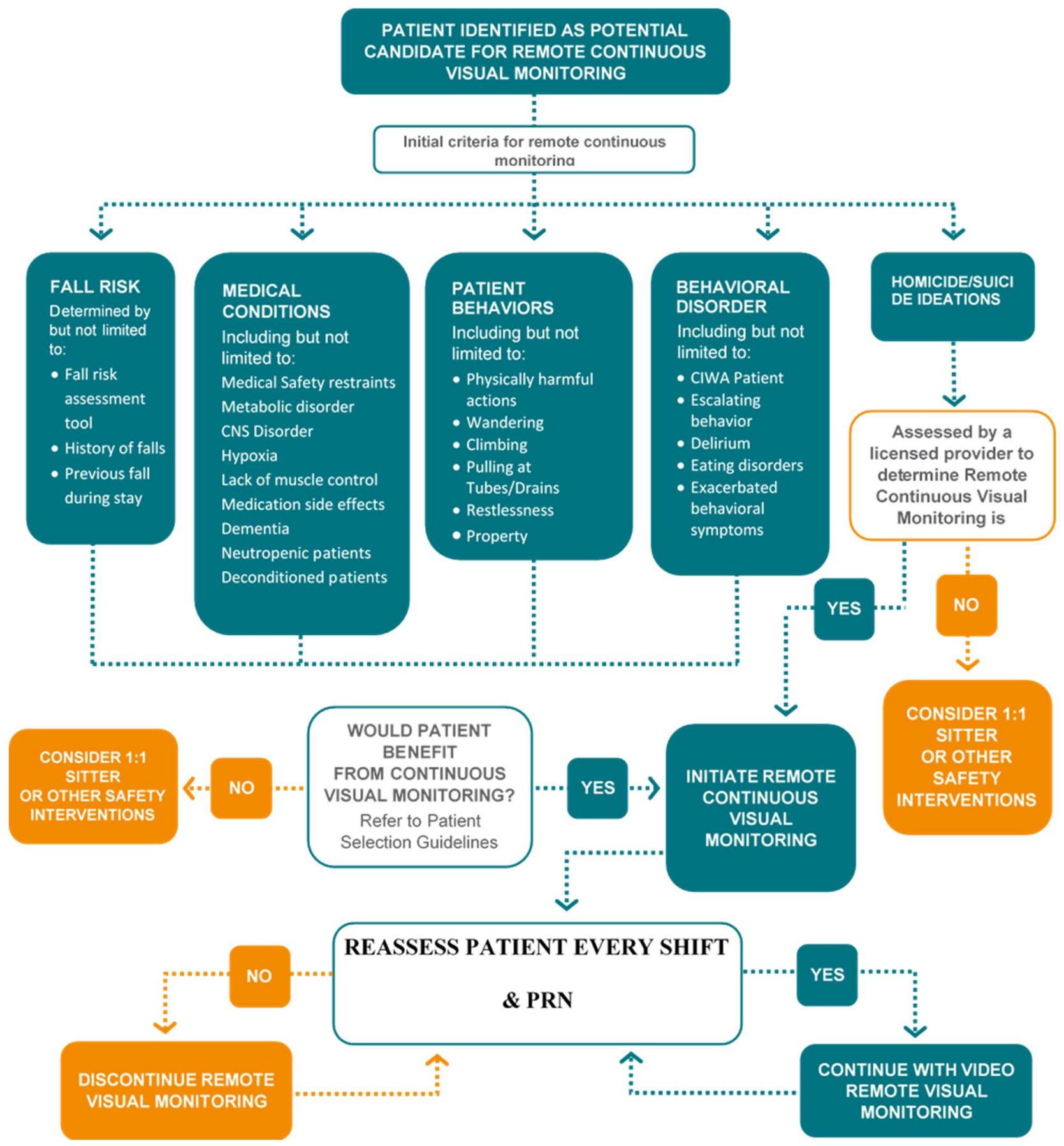


REDUCING FALLS AMONG ACUTE REHABILITATION PATIENTS....56

\section{Appendix I}

\section{Data Compilation Tool}

\begin{tabular}{|c|c|c|c|c|c|c|c|c|c|c|c|}
\hline \multirow{2}{*}{$\begin{array}{l}\text { Medical } \\
\text { Record } \\
\text { Number }\end{array}$} & \multirow{2}{*}{$\begin{array}{l}\text { Admit } \\
\text { Date }\end{array}$} & \multirow[t]{2}{*}{ Unit } & \multirow{2}{*}{$\begin{array}{l}\text { Medical } \\
\text { Diagnosis }\end{array}$} & \multirow{2}{*}{\begin{tabular}{|l|} 
EMR \\
Documentat \\
ion \\
YN \\
\end{tabular}} & \multirow{2}{*}{$\begin{array}{l}\text { Fall Risk } \\
\text { Category } \\
\text { L, M, H }\end{array}$} & \multirow{2}{*}{$\begin{array}{l}\text { Fall } \\
\text { YN }\end{array}$} & \multirow{2}{*}{\begin{tabular}{|l|} 
Safety \\
Intelligence \\
Report Y/N
\end{tabular}} & \multirow{2}{*}{$\begin{array}{l}\text { TeleSitter } \\
\text { YN }\end{array}$} & \multirow{2}{*}{$\begin{array}{l}\text { Bed } \\
\text { Alarm } \\
\text { Y/N }\end{array}$} & \multicolumn{2}{|c|}{ Fall Occurence } \\
\hline & & & & & & & & & & I\& Fall & \begin{tabular}{|l} 
Repeat \\
Fall
\end{tabular} \\
\hline & & & & & & & & & & & \\
\hline & & & & & & & & & & & \\
\hline & & & & & & & & & & & \\
\hline & & & & & & & & & & & \\
\hline & & & & & & & & & & & \\
\hline & & & & & & & & & & & \\
\hline & & & & & & & & & & & \\
\hline & & & & & & & & & & & \\
\hline & & & & & & & & & & & \\
\hline & & & & & & & & & & & \\
\hline & & & & & & & & & & & \\
\hline & & & & & & & & & & & \\
\hline & & & & & & & & & & & \\
\hline & & & & & & & & & & & \\
\hline & & & & & & & & & & & \\
\hline
\end{tabular}




\section{Appendix J}

\section{GANTT Chart}

Implementation of Video Monitoring System to Reduce Prevalence of Falls Pre-Planning

Collaborative meeting to review current fall data

Clarified process and cause of process variations (flowchart and Fishbone diagram

Develop project plan

Define PICOT question

Perform literature review and review of evidence

Identify theoretical framework and change model

Identify external and internal stakeholders

\section{Planning}

Complete policies and procedures including defining inclusion and exclusion criteria

\section{Identify gaps and} staffing needs

Develop Nursing staffing plan for te Video monitoring (VM) for unit staff and the monitors including hiring process

Coordinate equipment request approval and purchase

\section{Project \\ Manager}

(PM)

PM

PM

PM

PM

PM

PM

PM

Mon 2/17/20

Mon 2/17/20

PM

Mon 2/17/20

PM

Thu $2 / 20 / 20$

Sun $2 / 23 / 20$

PM

PM

Mon 2/24/20

Wed $02 / 26 / 220$

Wed $2 / 26 / 20$

\section{Logistical Assessment and Readiness}

\begin{tabular}{|c|c|c|c|c|}
\hline Identify vendor for VM & $\mathrm{ClO}$ & $\mathrm{ClO}$ & Mon $7 / 6 / 20$ & Mon $9 / 07 / 20$ \\
\hline $\begin{array}{l}\text { Assess technical needs } \\
\text { after review of } \\
\text { specification }\end{array}$ & $\mathrm{ClO}$ & IT staff & Mon $7 / 6 / 20$ & Mon $9 / 07 / 20$ \\
\hline $\begin{array}{l}\text { Assign IT staff to assess } \\
\text { hospital readiness, } \\
\text { security, and privacy } \\
\text { needs }\end{array}$ & $\mathrm{ClO}$ & $\mathrm{ClO}$ & Mon 7/6/20 & Mon 9/07/20 \\
\hline
\end{tabular}




\begin{tabular}{|c|c|c|c|c|}
\hline $\begin{array}{l}\text { Ensure documentation } \\
\text { platform and EHR is } \\
\text { ready }\end{array}$ & $\mathrm{ClO}$ & IT staff & Mon $7 / 6 / 20$ & Mon 9/07/20 \\
\hline $\begin{array}{l}\text { Conduct testing for } \\
\text { connectivity and remote } \\
\text { access }\end{array}$ & $\mathrm{ClO}$ & IT staff & Mon $7 / 6 / 20$ & Mon $9 / 07 / 20$ \\
\hline $\begin{array}{l}\text { Establish down time } \\
\text { procedures }\end{array}$ & $\mathrm{ClO}$ & IT staff & Mon 7/6/20 & Mon 9/07/20 \\
\hline $\begin{array}{l}\text { Coordinate vendor and } \\
\text { project team } \\
\text { communication weekly } \\
\text { teleconference }\end{array}$ & $\mathrm{ClO}$ & IT staff & Mon 7/6/20 & Mon $9 / 07 / 20$ \\
\hline $\begin{array}{l}\text { Coordinate Go-live and } \\
\text { implementation }\end{array}$ & $\mathrm{ClO}$ & IT staff & Mon $7 / 6 / 20$ & Mon 9/07/20 \\
\hline Workflow process & Pre-Go I & ive Tasks & & - \\
\hline $\begin{array}{l}\text { Define inclusion and } \\
\text { exclusion criteria }\end{array}$ & CNO & & Wed $7 / 15 / 20$ & Fri 09/18/20 \\
\hline $\begin{array}{l}\text { Define floor staff and } \\
\text { house supervisor } \\
\text { responsibilities }\end{array}$ & $\mathrm{CNO}$ & HR staff & Wed $7 / 15 / 20$ & Fri 09/18/20 \\
\hline $\begin{array}{l}\text { Define monitor tech } \\
\text { responsibilities }\end{array}$ & $\mathrm{CNO}$ & HR staff & Wed $7 / 15 / 20$ & Fri 09/18/20 \\
\hline $\begin{array}{l}\text { Define patient and } \\
\text { family awareness } \\
\text { process }\end{array}$ & $\begin{array}{l}\text { Director } \\
\text { Education }\end{array}$ & Education staff & Wed $7 / 15 / 20$ & Fri 09/18/20 \\
\hline Define cleaning process & $\mathrm{CNO}$ & $\begin{array}{l}\text { Nursing } \\
\text { Leadership }\end{array}$ & Wed $7 / 15 / 20$ & Fri 09/18/20 \\
\hline $\begin{array}{l}\text { Develop admission and } \\
\text { discontinuation process }\end{array}$ & $\mathrm{CNO}$ & $\begin{array}{l}\text { Nursing } \\
\text { Leadership }\end{array}$ & Wed $7 / 15 / 20$ & Fri 09/18/20 \\
\hline Logistical Process & & & & \\
\hline $\begin{array}{l}\text { Determine storage } \\
\text { location for devices not } \\
\text { in use }\end{array}$ & $\mathrm{CNO}$ & $\begin{array}{l}\text { Nursing } \\
\text { Leadership }\end{array}$ & Mon 07/20/20 & Mon $09 / 21 / 20$ \\
\hline $\begin{array}{l}\text { Determine process for } \\
\text { transport of device from } \\
\text { storage }\end{array}$ & $\mathrm{CNO}$ & $\begin{array}{l}\text { Nursing } \\
\text { Leadership }\end{array}$ & Mon $07 / 20 / 20$ & Mon 09/21/20 \\
\hline $\begin{array}{l}\text { Determine for tracking } \\
\text { VM devices }\end{array}$ & $\mathrm{CNO}$ & $\begin{array}{l}\text { Nursing } \\
\text { Leadership }\end{array}$ & Mon $07 / 20 / 20$ & Mon $09 / 21 / 20$ \\
\hline $\begin{array}{l}\text { Define change of shift } \\
\text { communication for RN } \\
\text { and monitoring techs } \\
\text { including escalation } \\
\text { process and STAT abort } \\
\text { protocol }\end{array}$ & $\mathrm{CNO}$ & $\begin{array}{c}\text { Nursing } \\
\text { Leadership }\end{array}$ & Mon $07 / 20 / 20$ & Mon $09 / 21 / 20$ \\
\hline
\end{tabular}

\section{Education and} training

Identify training needs of new and existing staff-floor, supervisor, and monitor techs

\begin{tabular}{|c|c|}
\hline $\begin{array}{l}\text { Education } \\
\text { Director }\end{array}$ & $\begin{array}{l}\text { Nursing } \\
\text { Education staff }\end{array}$ \\
\hline
\end{tabular}


REDUCING FALLS AMONG ACUTE REHABILITATION PATIENTS....59

\begin{tabular}{|c|c|c|c|c|}
\hline $\begin{array}{l}\text { Develop educational } \\
\text { plan }\end{array}$ & $\begin{array}{l}\text { Education } \\
\text { Director }\end{array}$ & $\begin{array}{c}\text { Nursing } \\
\text { Education staff }\end{array}$ & Mon $7 / 6 / 20$ & Mon $9 / 28 / 20$ \\
\hline $\begin{array}{l}\text { Complete education of } \\
\text { staff and patients }\end{array}$ & $\begin{array}{l}\text { Education } \\
\text { Director }\end{array}$ & $\begin{array}{c}\text { Nursing } \\
\text { Education staff }\end{array}$ & Mon $7 / 6 / 20$ & Mon $9 / 28 / 20$ \\
\hline \multicolumn{5}{|l|}{$\begin{array}{l}\text { Communication } \\
\text { Plan }\end{array}$} \\
\hline $\begin{array}{l}\text { Coordinate project } \\
\text { meetings with staff and } \\
\text { stakeholders }\end{array}$ & PM & $\begin{array}{c}\text { Hospital } \\
\text { leadership and } \\
\text { PM }\end{array}$ & Mon 11/02/20 & Sun $1 / 31 / 21$ \\
\hline $\begin{array}{l}\text { Communicate with the } \\
\text { leadership, } \\
\text { stakeholders, and } \\
\text { process owners } \\
\text { (frontline staff) weekly to } \\
\text { report the progress of } \\
\text { the project. }\end{array}$ & PM & $\begin{array}{c}\text { Hospital } \\
\text { leadership and } \\
\text { PM }\end{array}$ & Mon 11/02/20 & Sun $1 / 31 / 21$ \\
\hline $\begin{array}{l}\text { Report the progress to } \\
\text { the Hospital-wide Falls } \\
\text { Committee and the } \\
\text { Quality Safety and Risk } \\
\text { Management } \\
\text { Committee on monthly } \\
\text { basis. }\end{array}$ & PM & $\begin{array}{c}\text { Hospital } \\
\text { leadership and } \\
\text { PM }\end{array}$ & Mon 11/02/20 & Fri $1 / 29 / 21$ \\
\hline \multicolumn{5}{|l|}{ Proposal } \\
\hline $\begin{array}{l}\text { Submit proposal to } \\
\text { USAHS EPRC }\end{array}$ & PM & PM & Tue 10/13/20 & Fri $10 / 16 / 20$ \\
\hline $\begin{array}{l}\text { Submit proposal to } \\
\text { Rancho EBPC }\end{array}$ & PM & $\mathrm{PM} / \mathrm{CNO}$ & Mon 10/19/20 & Wed $10 / 21 / 20$ \\
\hline \multicolumn{5}{|l|}{$\begin{array}{l}\text { Go Live } \\
\text { Implementation }\end{array}$} \\
\hline $\begin{array}{l}\text { Implement the VM } \\
\text { process in pilot unit TBI } \\
1 \text { North }\end{array}$ & $\mathrm{ClO}$ & Nursing and IT & Mon 11/01/20 & Tue $12 / 15 / 20$ \\
\hline \multicolumn{5}{|l|}{$\begin{array}{l}\text { Data Collection/ } \\
\text { Analysis }\end{array}$} \\
\hline $\begin{array}{l}\text { Establish data collection } \\
\text { process }\end{array}$ & PM & $\begin{array}{l}\text { CNO/QRM } \\
\text { Director }\end{array}$ & Mon 11/02/20 & Tue $12 / 15 / 20$ \\
\hline $\begin{array}{l}\text { Establish data analysis } \\
\text { and reporting process }\end{array}$ & PM & $\begin{array}{l}\text { CNO/QRM } \\
\text { Director }\end{array}$ & Wed $12 / 16 / 20$ & Fri 01/15/20 \\
\hline $\begin{array}{l}\text { Evaluate project } \\
\text { effectiveness }\end{array}$ & PM & $\begin{array}{c}\text { Hospital } \\
\text { leadership and } \\
\text { PM }\end{array}$ & Fri 1/29/21 & Fri 1/29/21 \\
\hline $\begin{array}{l}\text { Celebrate } \\
\text { success }\end{array}$ & PM & $\begin{array}{c}\text { Hospital } \\
\text { leadership and } \\
\text { PM }\end{array}$ & Mon 2/01/21 & Mon 2/01/21 \\
\hline
\end{tabular}




\section{Appendix K}

\section{Budget}

\begin{tabular}{|c|c|c|}
\hline EXPENSES & insure & REVENUE \\
\hline Direct & & Billing \\
\hline $\begin{array}{l}\text { Salary and benefits (4.2 FTE for } \\
\text { Video Monitor Technicians) }\end{array}$ & $\$ 168,000$ & \\
\hline Supplies & & Institutional budget support \\
\hline $\begin{array}{l}12 \text { Avasure Telesitter (video } \\
\text { monitors) }\end{array}$ & $\$ 137,239$ & \\
\hline 2 Chairs & $\$ 999.02$ & \\
\hline TV Desk Mount & $\$ 65.09$ & \\
\hline 48- inch monitor & $\$ 667.00$ & \\
\hline Height adjustable desk & $\$ 3781.75$ & \\
\hline 16 Headphones & $\$ 1326.88$ & \\
\hline 2 Adapters & $\$ 46.92$ & \\
\hline Services & & \\
\hline Avasure Implementation Service & $\$ 40,730$ & \\
\hline AvaNet & $\$ 17,703$ & \\
\hline ORNA SLA & $\$ 12,000$ & \\
\hline Total Expenses & $\$ 312,126.01$ & Total Revenue \\
\hline \multicolumn{3}{|l|}{ Net Balance } \\
\hline
\end{tabular}


Appendix L

\section{Measures}

\begin{tabular}{|c|c|c|c|c|c|c|c|c|c|c|c|c|c|c|c|c|c|c|}
\hline \multicolumn{9}{|c|}{ Project Design: Pre-implementation and post implementation design is quantitative design } & 1 & & & & & & & & & \\
\hline \multicolumn{19}{|c|}{ An evidence-based project reducing the prevalence of falls and injurious falls by implementing a video monitoring system in the traumatic brain injury inpatient rehabilitation unit. } \\
\hline \multirow[t]{2}{*}{ MEASURES } & \multirow{2}{*}{\multicolumn{2}{|c|}{ QUTCON.PROCE }} & \multicolumn{4}{|c|}{ CATEGORIES } & \multicolumn{4}{|c|}{ TIMEFor DATA COLLECTION } & \multicolumn{4}{|c|}{ STATISTICALTEST } & \multirow{2}{*}{$\begin{array}{l}\text { BASELINE } \\
\text { Values }\end{array}$} & \multicolumn{3}{|c|}{ GOAL } \\
\hline & & & BALANCII & I FINANCl: & | SUSTAINABN & I CONTE: & Baselin & n Weekly & yo days & 45 days & $\begin{array}{l}\text { paired } \\
\text { t-test }\end{array}$ & $\begin{array}{l}\text { unpaired } \\
\text { t-test }\end{array}$ & $x^{2}$ & Other & & \multicolumn{3}{|c|}{ Weekly 30 days 45 days } \\
\hline $\begin{array}{l}\text { Number of falls for the } \\
\text { TBI }\end{array}$ & $x$ & & & & & $x$ & $x$ & $x$ & $x$ & $x$ & & $x$ & $x$ & & & & & \\
\hline $\begin{array}{l}\text { Number of falls on other } \\
\text { Rehab Unit }\end{array}$ & $x$ & & & & & & & & 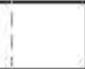 & & & $x$ & & & & & & \\
\hline $\begin{array}{l}\text { Rate of hospital falls per } \\
1,000 \text { patient days. } \\
\text { (The denominator is the } \\
\text { calculated inpatient days } \\
\text { The numerator is the total } \\
\text { number of hospital falls. }\end{array}$ & & & & & & & & & : & & & & $x$ & & $\begin{array}{c}4.57 \text { per } 1,000 \text { patient } \\
\text { days }\end{array}$ & $\begin{array}{c}25 \% \\
\text { reducti } \\
\text { on from } \\
4.57 \\
(4.34)\end{array}$ & $\mid \begin{array}{c}210 \% \\
\text { reducti } \\
\text { on from } \\
4.57 \\
(4.113)\end{array}$ & $\begin{array}{c}220 \% \\
\text { reducti } \\
\text { on from } \\
4.57 \\
(3.65)\end{array}$ \\
\hline $\begin{array}{l}\text { Rate of fall for adult TBI } \\
\text { patients. (The denominator } \\
\text { is calculated inpatient days). } \\
\text { The numerator is the total } \\
\text { number ofadult TBl patients }\end{array}$ & $x$ & & & & & $x$ & $x$ & 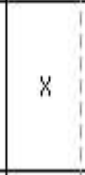 & 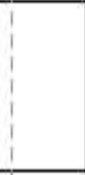 & & & & $x$ & & $\begin{array}{l}6.2 \text { per } 1,000 \text { patient } \\
\text { days }\end{array}$ & \begin{tabular}{|c|}
$25 \%$ \\
reducti \\
on from \\
6.2 \\
$(5.89)$ \\
\end{tabular} & \begin{tabular}{|c|}
$210 \%$ \\
reducti \\
on from \\
6.2 \\
$(5.58)$ \\
\end{tabular} & $\begin{array}{c}220 \% \\
\text { reducti } \\
\text { on from } \\
6.2 \\
{[4.96]} \\
\end{array}$ \\
\hline $\begin{array}{l}\text { Rate of video monitring } \\
\text { usage for TBI patients. } \\
\text { (The deoniminator is the total } \\
\text { number of available video } \\
\text { monitoring machines. The } \\
\text { numerator is the total number } \\
\text { of adult TBI patients who used }\end{array}$ & & $x$ & & & $x$ & & $x$ & 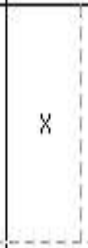 & is & $x$ & $x$ & & $x$ & & no data available & $\begin{array}{l}270 \% \\
\text { usage }\end{array}$ & $\begin{array}{l}280 \% \\
\text { usage }\end{array}$ & $\begin{array}{l}290 \% \\
\text { usage }\end{array}$ \\
\hline $\begin{array}{l}\text { Percent of adult TBI } \\
\text { patients who qualified for } \\
\text { video monitoring. (The } \\
\text { denominator is the total } \\
\text { number of adult TBl patients.. } \\
\text { The numerator is total number } \\
\text { of adult TBI patients who } \\
\text { qualified for video monitoring }\end{array}$ & & $x$ & & & $x$ & & $x$ & & 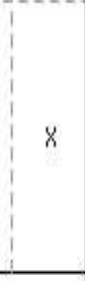 & $x$ & & $x$ & & & $50 \%$ & $260 \%$ & $275 \%$ & $285 \%$ \\
\hline hate or doulc (B) & & & & & & & & & 1 & & & & & & & & & \\
\hline
\end{tabular}

